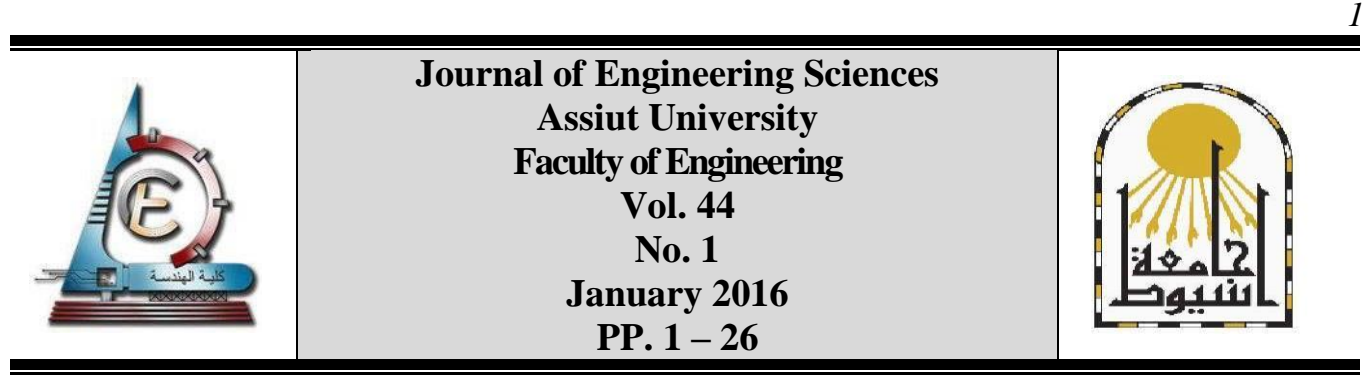

\title{
EFFECT OF SHEAR SPAN TO DEPTH RATIO ON THE STATICAL BEHAVIOR OF HSCB SUBJECTED TO TRANSVERSE LOADING
}

\author{
Abd El Rahman Megahid ${ }^{1}$, Mohamed M. Rashwan ${ }^{2}$, \\ Mohamed Mahmoud ${ }^{3}$ and Amr Abd El Aal ${ }^{*}, 4$ \\ $1,2,3$ staff in Civil Eng. Department, Faculty of Engineering, Assiut University, Assiut, Egypt.
${ }^{4}$ Civil Engineer, Assiut University, 2009.
}

Received 26 November 2015; Accepted 10 December 2015

\begin{abstract}
Many researches were carried out to investigate the properties and structural performance of high strength concrete for many decades. While these researches have produced relevant and useful results, there are several properties of high strength concrete like compressive and tensile strengths, stiffness, durability, modulus of rupture, cracking shear load and ultimate load that need to investigate to determine an accurate evaluation of beams made of high strength concrete.

This study investigates the effect of shear span-depth ratio $(\mathrm{a} / \mathrm{d})$ on the statical behavior of HSCB subjected to transverse loading. The effect of shear span to depth ratio includes some main mutual factors such as grade of concrete and stirrups spacing. The studied statical behavior includes: evaluation of pattern of cracks, modes of failure, concrete and steel strains, maximum deflection, flexural cracking load $\left(\mathrm{P}_{\mathrm{cr}}\right)$, modulus of rupture, cracking shear load $\left(\mathrm{V}_{\mathrm{cr}}\right)$ and finally ultimate load $\left(\mathrm{P}_{\mathrm{u}}\right)$.

For this purpose, an experimental test program was performed which included testing twenty four large scale simply supported rectangular high strength concrete beams under one concentrated transverse load at mid span. The values of the main factors were; the shear span to depth ratio $(\mathrm{a} / \mathrm{d})$ were taken $(3,2,1.5$ and 1$)$, the cube compressive strength $\left(f_{\mathrm{cu}}\right)$ were $(575,766$ and 890$) \mathrm{kg} / \mathrm{cm}^{2}$ and the stirrups spacing were $(20,14.28,11.11$ and without stirrups) $\mathrm{cm}$, while the longitudinal reinforcement was kept constant for all tested beams.

For all tested beams, max. Deflections, strains in the longitudinal reinforcement, and strains in concrete were measured and recorded. Also, the initiation and propagation of cracks were recorded. Cracking patterns and failure modes were observed. Cracking and failure loads were recorded. The test results were compared with different codes and formulas.

Based on this, conclusions were drawn out for induced measured maximum deflection, steel and concrete strain, the cracking load the modulus of rupture, shear cracking load and ultimate load for beams with and without stirrups. In addition, ultimate shear load for beams without stirrups utilizing different code provisions was predicted and compared with the obtained test results.
\end{abstract}

Keywords: high strength concrete, shear span-depth ratio (a/d), compressive strength. 


\section{Introduction}

A worldwide use of high strength concrete during the last decade and an expansion in the material technology has made it possible to design concrete having superior mechanical properties and structural behavior. High strength concrete has become an economical solution and found its application in a number of concrete structures, the most common applications being the columns of high rise buildings, long span bridges, longer spans for beams or fewer beams for a given span length and offshore structures. It will be more and more frequently used in columns, as well as in precast elements. Many researchers have conducted investigations on the behavior of structural elements constructed of high strength concrete. However, analysis of these revealed that findings are inconsistent.

While use of high strength concrete has accelerated, the progress in development of revised design standards have not progressed at the same rate. Acceleration is due to its enhanced mechanical properties and better structural performance as compared to normal strength concrete. Also High Strength Concrete offers economy and superior performance in terms of strength and long-term behavior.

High strength concrete (HSC) is a relative term and has changed its meaning with time and the increase in the productivity of concretes with higher strengths. According to ACI 318-08 code and ACI 363-R, HSC is defined as concrete with strength more than (41.1) MPa or greater.

HSC have been achieved with Reactive Powder Concrete, which made of powders with no aggregate. These advances have been made possible by two major developments: the introduction of high range water-reducing admixtures (super plasticizers) and the use of silica fume. The admixtures allow the production of workable concrete mixtures with very low water-cement ratios, and the silica fume can produce cement paste with very low porosity, which increases the strength of both the paste and the interface between the paste and the coarse aggregate, this leads the cracks to propagate through coarse aggregate particles rather than around them. However an increase in the strength of the concrete produces an increase in its brittleness and smoother shear failure surfaces, leading to some concerns about the application of HSC.

HSC is usually proportioned with a low water-to cementations materials ratio. The supplementary cementations materials may include blast furnace slag, fly ash, or silica fume, which are used either as cement replacement or as additives to the concrete mixture. The Silica fume has the big role to improving the properties of hardened concrete.

In spite of the many investigations of properties of HSC, controversy still remains with regard to some vital design issues such as serviceability requirement of deflection, modulus of rupture, shear strength, ductility, cracks and the effect of shear span -depth ratio on the modes of failure of R.C. Beams.

\section{Experimental work}

Twenty four reinforced high strength concrete beams were cast. All beams were simply supported and loaded with concentrated transverse load at the mid span and applied at the top of the Beams. The test program was designed to include the main parameters affecting the general behavior of high strength of tested beams. The main parameters were: Shear span- depth ratio, $(\mathrm{a} / \mathrm{d}=3,2,1.5$ and 1$)$, three target concrete compressive strengths of (500, 700 , and 900$) \mathrm{kg} / \mathrm{cm}^{2}$ were used, and the stirrups spacing were $\left(5 \varnothing 8 / \mathrm{m}^{\prime}, 7 \varnothing 8 / \mathrm{m}^{\prime}, 9 \varnothing 8 / \mathrm{m}^{\prime}\right.$ 
Amr Abd El Aal et al., effect of shear span to depth ratio on the statical behavior of HSCB......

and without stirrups), which are equivalent in centimeters (20, 14.28, 11.11and without stirrups) cm respectively.

All beams have rectangular cross sections of width $(b=200 \mathrm{~mm})$ and effective depth $(d=559 \mathrm{~mm})$. The longitudinal steel reinforcement percentage was kept constant $(\rho=0.54$ $\%)$, it consisted of three bars each of diameter $16 \mathrm{~mm}$ having high tensile steel grade (40/60). The stirrups were made from ordinary mild steel with grade (24/35) having diameter of $8 \mathrm{~mm}$. Two steel bars each of diameter $10 \mathrm{~mm}$ made of high tensile steel with grade (40/60) were used as stirrup hangers. Details for the chosen reinforced concrete beams having the included studied parameters are given in table (1).

Table 1.

Details of the tested beams

\begin{tabular}{|c|c|c|c|c|c|c|c|c|c|}
\hline $\begin{array}{c}\text { Group } \\
\text { No. }\end{array}$ & $\begin{array}{l}\text { Beam } \\
\text { No. }\end{array}$ & $\underset{\left(\mathrm{kg} / \mathrm{cm}^{2}\right)}{\mathrm{f}_{\mathrm{cu}}}$ & $\mathrm{a} / \mathrm{d}$ & $\begin{array}{c}\mathrm{L} \\
(\mathrm{cm})\end{array}$ & $\begin{array}{l}\text { Shear } \\
\text { span } \\
(\mathrm{cm})\end{array}$ & $\begin{array}{l}\text { Main } \\
\text { steel }\end{array}$ & $\begin{array}{c}\text { Stirrups } \\
\text { Spacing } \\
(\mathrm{cm})\end{array}$ & $\rho \%$ & $\rho_{v} \%$ \\
\hline \multirow{4}{*}{ G1 } & B1-1 & \multirow{4}{*}{575} & 3 & 335 & 167.5 & \multirow{4}{*}{$3 \phi 16$} & \multirow{4}{*}{$\begin{array}{c}20 \\
\left(5 \varnothing 8 / \mathrm{m}^{\prime}\right)\end{array}$} & \multirow{4}{*}{0.54} & \multirow{4}{*}{0.25} \\
\hline & B1-2 & & 2 & 224 & 112 & & & & \\
\hline & B1-3 & & 1.5 & 167 & 83.5 & & & & \\
\hline & B1-4 & & 1 & 112 & 56 & & & & \\
\hline \multirow{4}{*}{$\mathrm{G} 2$} & B2-1 & \multirow{4}{*}{766} & 3 & 335 & 167.5 & \multirow{4}{*}{$3 \phi 16$} & \multirow{4}{*}{$\begin{array}{c}20 \\
\left(5 \varnothing 8 / \mathrm{m}^{\prime}\right)\end{array}$} & \multirow{4}{*}{0.54} & \multirow{4}{*}{0.25} \\
\hline & B2-2 & & 2 & 224 & 112 & & & & \\
\hline & B2-3 & & 1.5 & 167 & 83.5 & & & & \\
\hline & B2-4 & & 1 & 112 & 56 & & & & \\
\hline \multirow{4}{*}{ G3 } & B3-1 & \multirow{4}{*}{890} & 3 & 335 & 167.5 & \multirow{4}{*}{$3 \phi 16$} & \multirow{4}{*}{$\begin{array}{c}20 \\
\left(5 \varnothing 8 / \mathrm{m}^{\prime}\right)\end{array}$} & \multirow{4}{*}{0.54} & \multirow{4}{*}{0.25} \\
\hline & B3-2 & & 2 & 224 & 112 & & & & \\
\hline & B3-3 & & 1.5 & 167 & 83.5 & & & & \\
\hline & B3-4 & & 1 & 112 & 56 & & & & \\
\hline \multirow{4}{*}{ G4 } & B4-1 & \multirow{4}{*}{766} & 3 & 335 & 167.5 & \multirow{4}{*}{$3 \phi 16$} & \multirow{4}{*}{$\begin{array}{c}14.28 \\
\left(7 \varnothing 8 / \mathrm{m}^{\prime}\right)\end{array}$} & \multirow{4}{*}{0.54} & \multirow{4}{*}{0.35} \\
\hline & B4-2 & & 2 & 224 & 112 & & & & \\
\hline & B4-3 & & 1.5 & 167 & 83.5 & & & & \\
\hline & B4-4 & & 1 & 112 & 56 & & & & \\
\hline \multirow{4}{*}{ G5 } & B5-1 & \multirow{4}{*}{766} & 3 & 335 & 167.5 & \multirow{4}{*}{$3 \phi 16$} & \multirow{4}{*}{$\begin{array}{c}11.11 \\
\left(9 \varnothing 8 / \mathrm{m}^{\prime}\right)\end{array}$} & \multirow{4}{*}{0.54} & \multirow{4}{*}{0.45} \\
\hline & B5-2 & & 2 & 224 & 112 & & & & \\
\hline & B5-3 & & 1.5 & 167 & 83.5 & & & & \\
\hline & B5-4 & & 1 & 112 & 56 & & & & \\
\hline \multirow{4}{*}{ G6 } & B6-1 & \multirow{4}{*}{766} & 3 & 335 & 167.5 & & & & \\
\hline & B6-2 & & 2 & 224 & 112 & 2416 & Without & 05 & 0 \\
\hline & B6-3 & & 1.5 & 167 & 83.5 & $3 \phi 16$ & stirrups & 0.54 & 0.00 \\
\hline & B6-4 & & 1 & 112 & 56 & & & & \\
\hline
\end{tabular}

2.1 Materials

\subsubsection{Concrete mixes design}

Concrete mixes used to produce high strength concrete are given in table (2). 
Table 2.

Concrete Mix Proportions

\begin{tabular}{|c|c|c|c|c|c|c|c|c|}
\hline Grade & $\begin{array}{c}\text { Cement } \\
\left(\mathrm{kg} / \mathrm{m}^{3}\right)\end{array}$ & $\begin{array}{c}\text { Silica } \\
\text { fume } \\
\left(\mathrm{kg} / \mathrm{m}^{3}\right)\end{array}$ & $\begin{array}{c}\text { Fine } \\
\text { aggregate } \\
\left(\mathrm{kg} / \mathrm{m}^{3}\right)\end{array}$ & $\begin{array}{c}\text { Coarse } \\
\text { aggregate } \\
(\text { Basalt }) \\
\left(\mathrm{kg} / \mathrm{m}^{3}\right)\end{array}$ & $\begin{array}{c}\text { Super } \\
\text { Plasticizer } \\
(\text { Liter/m }\end{array}$ & $\begin{array}{c}\text { Water } \\
\left(\text { liter/m }{ }^{3}\right)\end{array}$ & w/c & $\begin{array}{c}\text { Slump } \\
(\mathrm{cm})\end{array}$ \\
\hline 500 & 450 & 50 & 591 & 1182 & 12.5 & 143 & 0.318 & 16 \\
\hline 700 & 500 & 85 & 565 & 1130 & 15 & 138 & 0.276 & 14 \\
\hline 900 & 500 & 110 & 554 & 1108 & 18.5 & 135 & 0.27 & 14 \\
\hline
\end{tabular}

The constituent materials were:

1- Ordinary Portland cement, its properties agreed with ECP 203.

2- Crushed Bazalt; the used crushed basalt was $20 \mathrm{~mm}$ nominal max. size, 2.66 specific gravity, and $1.72 \mathrm{t} / \mathrm{m}^{3}$ volume weight.

3- Local sand natural desert sand which has a specific gravity and volume weight of 2.5 and $1.68 \mathrm{t} / \mathrm{m}^{3}$ respectively.

3- Potable water was used.

4- Superplastisizer; the used additive was Addicrete BVF having a density of $1.15 \mathrm{t} / \mathrm{m}^{3}$.

6- Silica fume (SF) is a by-product of the melting process used to produce silicon metal and ferrosilicon alloys. In this study, Silica fume was produced by Egyptian FerroAlloys Company (EFACO). The main characteristics of SF are its high content of amorphous ( $\mathrm{SiO} 2$ ) not less than $95 \%$, mean particle size of $0.1-0.2$ micron, the specific gravity is 2.2 , and the bulk density undensified (as produced) and densified about $300 \mathrm{~kg} / \mathrm{m}^{3}$ and (480 to 720 ) $\mathrm{kg} / \mathrm{m}^{3}$ respectively.

7- Steel Reinforcement: High tensile steel grade (40/60) having diameters $16 \mathrm{~mm}$ and 10 $\mathrm{mm}$ were used for longitudinal main steel and stirrups hanger, respectively. The stirrups were made from ordinary mild steel with grade (24/35) having diameter of $8 \mathrm{~mm}$.

\subsection{Test procedure}

All beams were tested after 28 days of casting under one concentrated transverse load and the beams were simply supported on two rigid supports, one support is roller to avoid restraint to the elongation of the bottom of fibers of the beams as load was applied, steel bearing plate $(10 \times 25 \times 1.25 \mathrm{~cm})$ was placed on each support to avoid bearing crush. The available hydraulic testing machine at Assiut University (500 tons) was used in testing all beams. The load was applied in increments of 1.0 ton at the beginning of the test until the first crack was observed then, the load increments were taken 2.0 tons until the final failure. The load was kept constant between every two successive increments for about 2 minutes to allow the measurement of the deflections and strains. During this period, the mid span max. Deflection was recorded, readings of strain gauges for longitudinal main steel and concrete compression extreme fibers were recorded, and cracks propagation was traced. After completion of the test, the beam was photographed to show the crack patterns. Test setup and arrangement and details of tested beams are shown in fig. (1). 
Amr Abd El Aal et al., effect of shear span to depth ratio on the statical behavior of HSCB......

\subsection{Instrumentation and measurement}

Deflection was measured under the loading point using dial gauge with accuracy of $0.01 \mathrm{~mm}$ having a maximum range of $50 \mathrm{~mm}$. It was placed at the position of mid span for each beam.

Electrical resistance strain gauges were used to measure the steel and concrete strains. Strain gauges with $10 \mathrm{~mm}$ length type (KFG) were used to measure the strain of longitudinal reinforcement and strain gauges with $67 \mathrm{~mm}$ length type $(\mathrm{KC})$ were selected to measure the compressive strain of concrete.
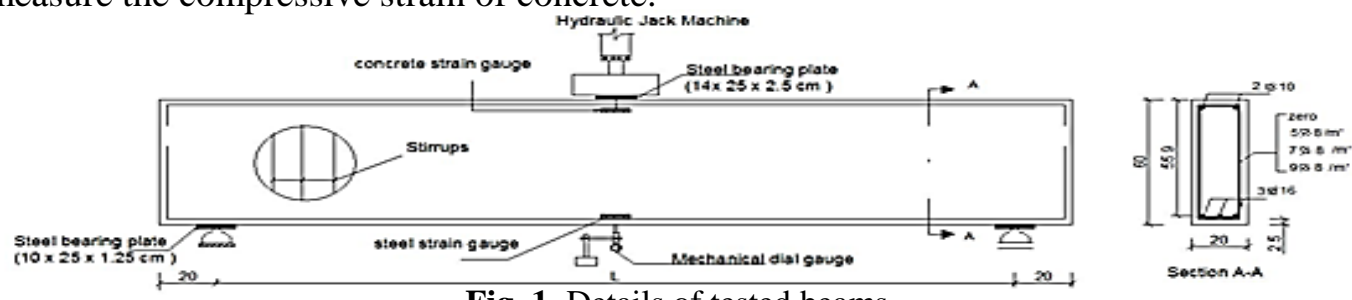

Fig. 1. Details of tested beams

\section{Test result}

\subsection{Crack patterns and modes of failure}

The crack patterns and mode of failure are evaluated for the tested reinforced high strength concrete (HSC) beams. Twenty four high strength concrete one span simply support beams were tested under static loading. The modes of failure, flexure cracking load, the diagonal cracking loads and ultimate load of the tested beams are summarized in table (3).The modes of failure were given also in table (3) and illustrated through from fig.(2)to fig.(25).

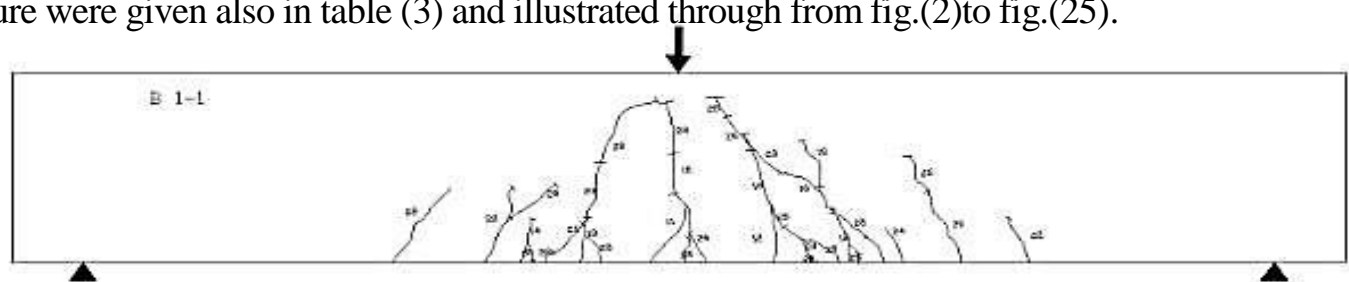

Fig. 2. Typical pattern of cracks for beam (B1-1) having $\mathrm{f}_{\mathrm{cu}}=575 \mathrm{~kg} / \mathrm{cm}^{2}$ and $\mathrm{a} / \mathrm{d}=3$

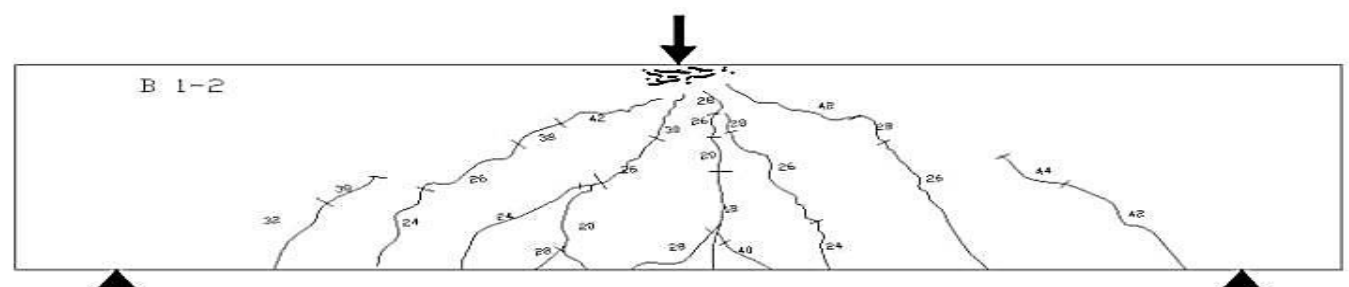

Fig. 3. Typical pattern of cracks for beam (B1-2) having fcu=575 kg/cm ${ }^{2}$ and $\mathrm{a} / \mathrm{d=2}$

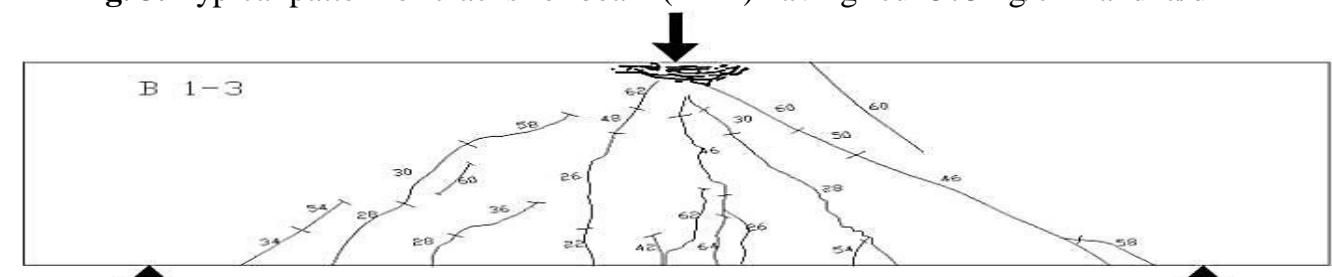

Fig. 4. Typical pattern of cracks for beam (B1-3) having fcu=575 kg/cm ${ }^{2}$ and $\mathrm{a} / \mathrm{d}=1.5$ 


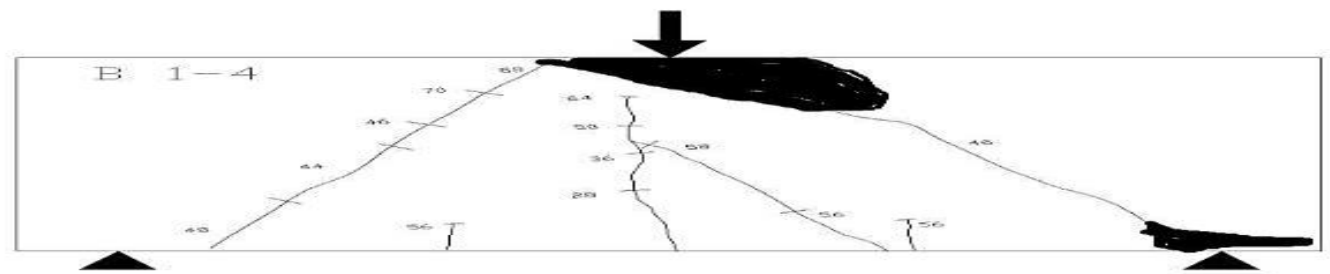

Fig. 5. Typical pattern of cracks for beam (B1-4) having fcu=575 $\mathrm{kg} / \mathrm{cm}^{2}$ and $\mathrm{a} / \mathrm{d}=1$

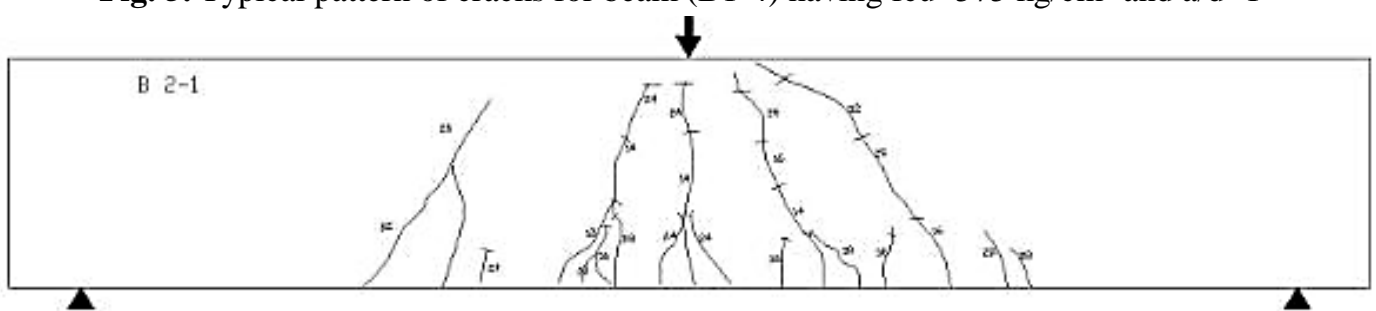

Fig. 6. Typical pattern of cracks for beam (B2-1) having $\mathrm{f}_{\mathrm{cu}}=766 \mathrm{~kg} / \mathrm{cm}^{2}$ and $\mathrm{a} / \mathrm{d}=3$

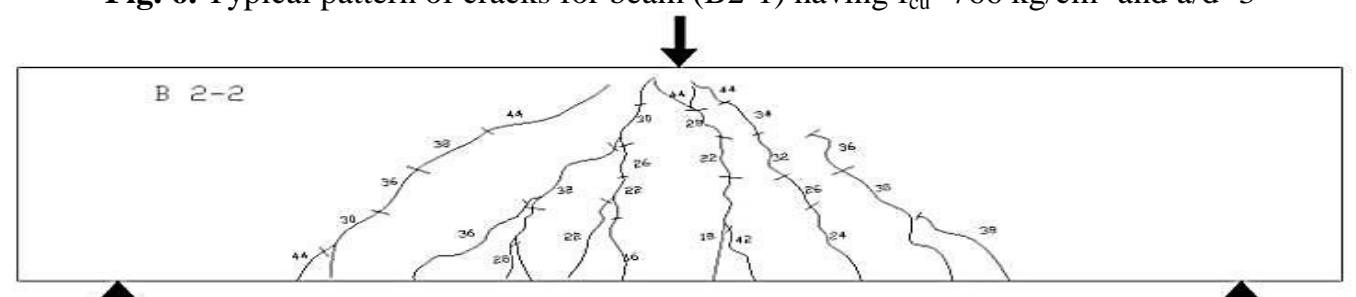

Fig. 7. Typical pattern of cracks for beam (B2-2) having $\mathrm{f}_{\mathrm{cu}}=766 \mathrm{~kg} / \mathrm{cm}^{2}$ and $\mathrm{a} / \mathrm{d}=2$
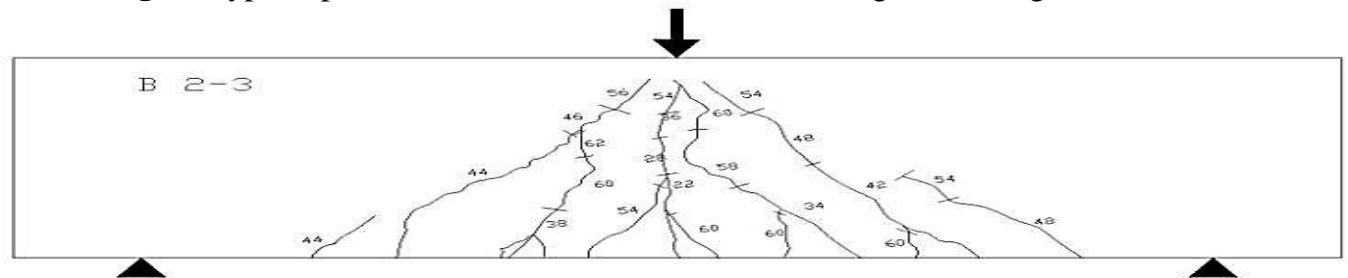

Fig. 8. Typical pattern of cracks for beam (B2-3) having $\mathrm{f}_{\mathrm{cu}}=766 \mathrm{~kg} / \mathrm{cm}^{2}$ and $\mathrm{a} / \mathrm{d}=1.5$

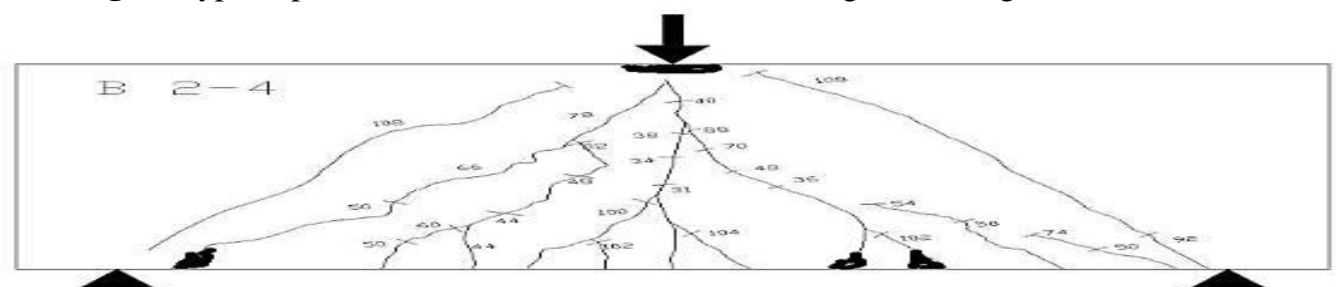

Fig. 9. Typical pattern of cracks for beam (B2-4) having $\mathrm{f}_{\text {cu }}=766 \mathrm{~kg} / \mathrm{cm}^{2}$ and $\mathrm{a} / \widehat{\mathrm{d}=1}$

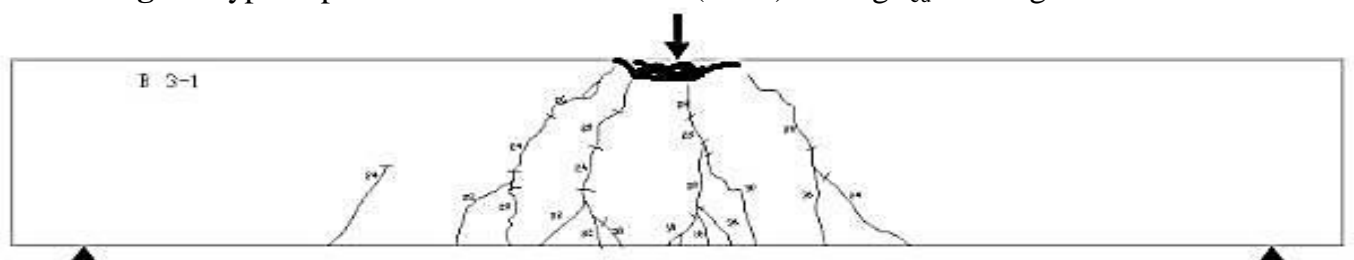

Fig. 10. Typical pattern of cracks for beam (B3-1) having $\mathrm{f}_{\mathrm{cu}}=890 \mathrm{~kg} / \mathrm{cm}^{2}$ and $\mathrm{a} / \mathrm{d}=\mathbf{A}$ 
B $3-2$

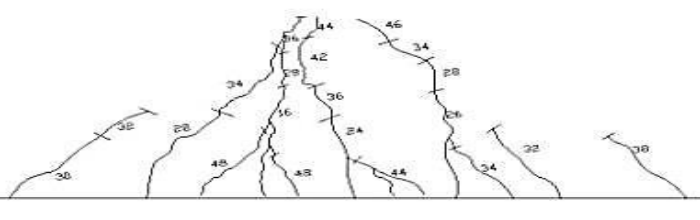

Fig. 11. Typical pattern of cracks for beam (B3-2) having $\mathrm{f}_{\mathrm{cu}}=890 \mathrm{~kg} / \mathrm{cm}^{2}$ and $\mathrm{a} / \mathrm{d}=2$

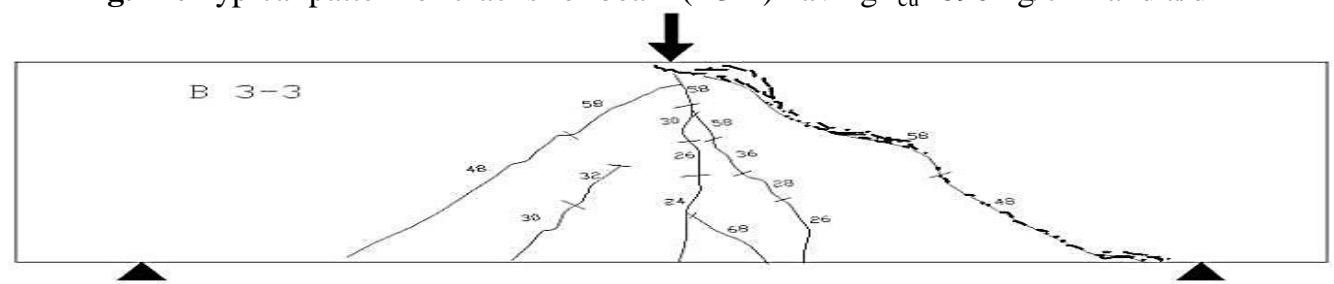

Fig. 12. Typical pattern of cracks for beam (B3-3) having $\mathrm{f}_{\mathrm{cu}}=890 \mathrm{~kg} / \mathrm{cm}^{2}$ and $\mathrm{a} / \mathrm{d}=1.5$

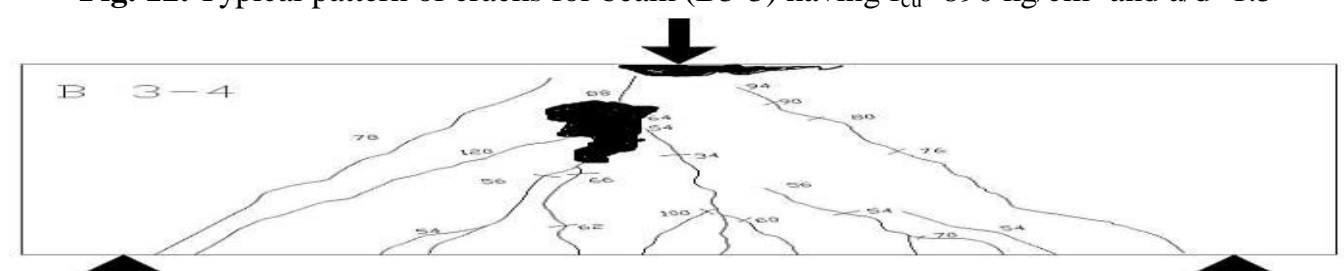

Fig. 13. Typical pattern of cracks for beam (B3-4) having $\mathrm{f}_{\mathrm{cu}}=890 \mathrm{~kg} / \mathrm{cm}^{2}$ and $\widehat{\mathrm{a} / \mathrm{d}=1}$

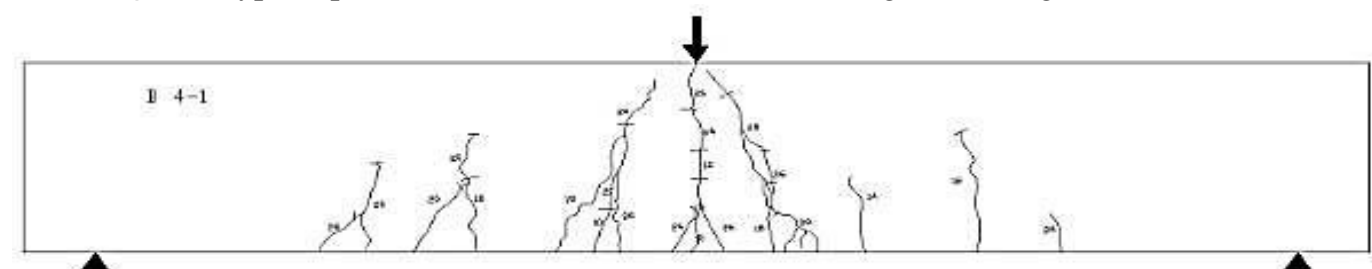

Fig. 14. Typical pattern of cracks for beam (B4-1) having $\mathrm{f}_{\mathrm{cu}}=766 \mathrm{~kg} / \mathrm{cm}^{2}$ and $\mathrm{a} / \mathrm{d}=3$
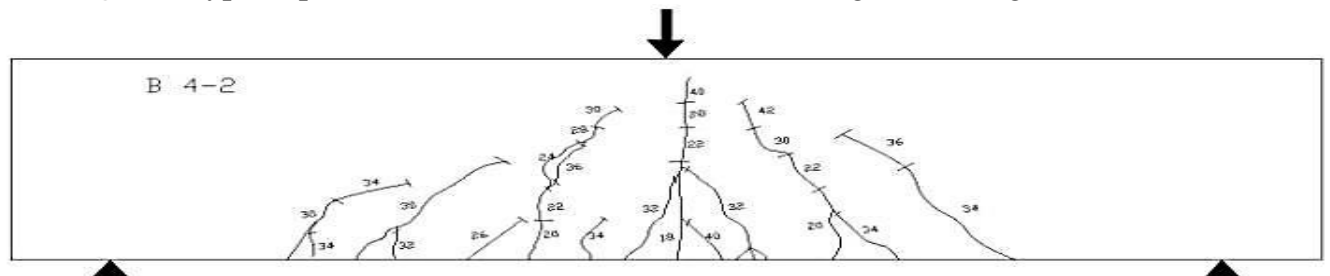

Fig. 15. Typical pattern of cracks for beam (B4-2) having $\mathrm{f}_{\mathrm{cu}}=766 \mathrm{~kg} / \mathrm{cm}^{2}$ and $\mathrm{a} / \mathrm{d}=\mathbf{2}$

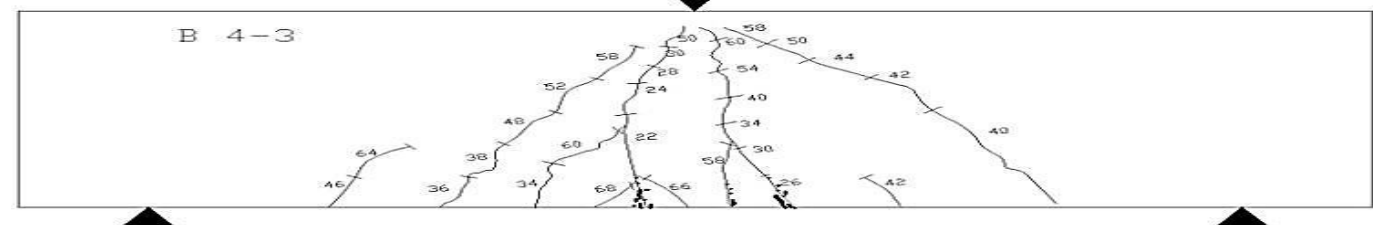

Fig. 16. Typical pattern of cracks for beam (B4-3) having $\mathrm{f}_{\mathrm{cu}}=766 \mathrm{~kg} / \mathrm{cm}^{2}$ and $\mathrm{a} / \mathrm{d}=1.5$ 


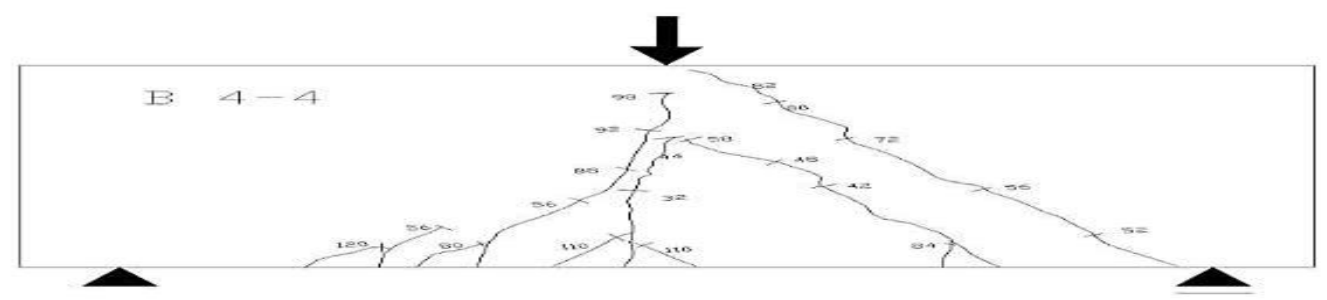

Fig. 17. Typical pattern of cracks for beam (B4-4) having $f_{c u}=766 \mathrm{~kg} / \mathrm{cm}^{2}$ and $\mathrm{a} / \mathrm{d}=1$

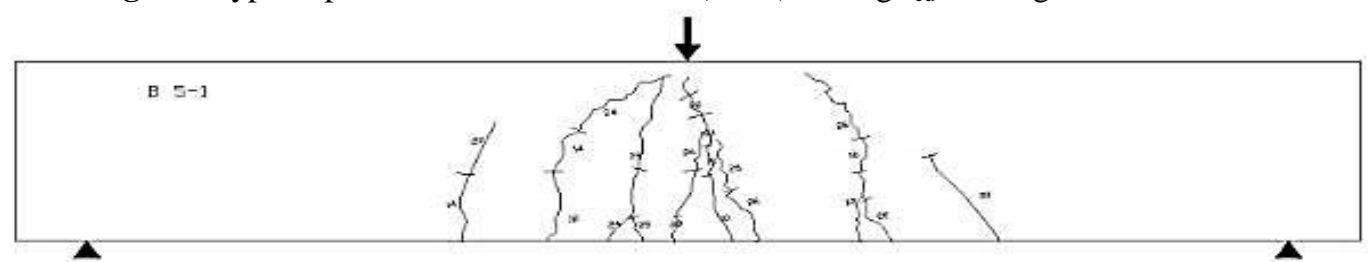

Fig. 18. Typical pattern of cracks for beam (B5-1) having $\mathrm{f}_{\mathrm{cu}}=766 \mathrm{~kg} / \mathrm{cm}^{2}$ and $\mathrm{a} / \mathrm{d}=3$
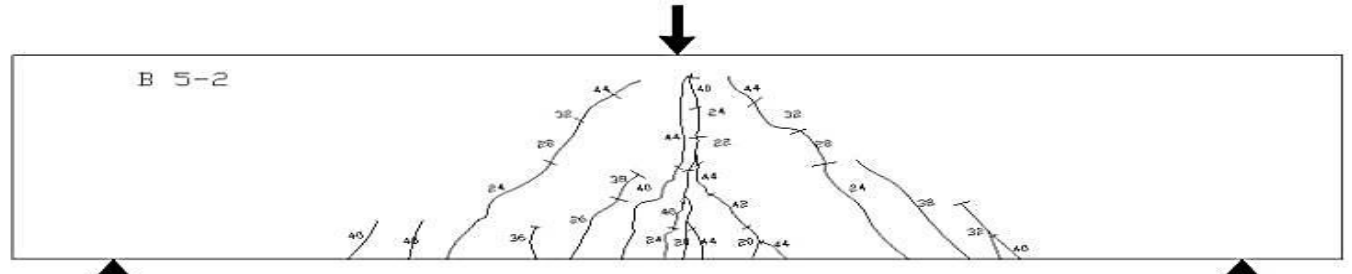

Fig. 19. Typical pattern of cracks for beam (B5-2) having $\mathrm{f}_{\mathrm{cu}}=766 \mathrm{~kg} / \mathrm{cm}^{2}$ and $\mathrm{a} / \mathrm{d}=2$

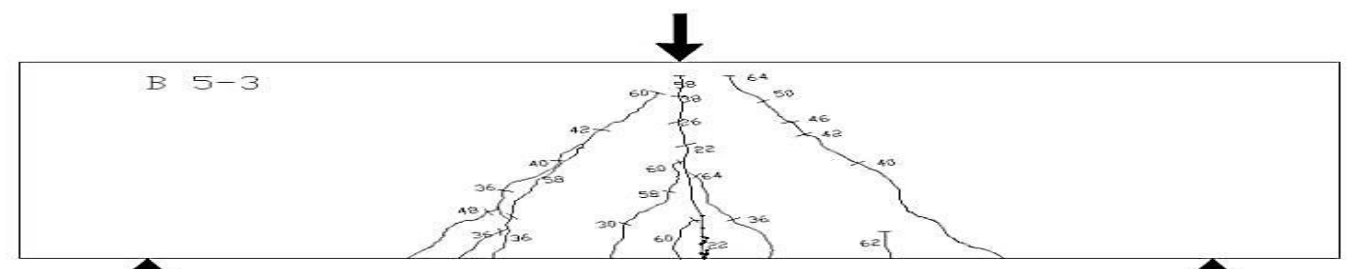

Fig. 20. Typical pattern of cracks for beam (B5-3) having $\mathrm{f}_{\mathrm{cu}}=766 \mathrm{~kg} / \mathrm{cm}^{2}$ and $\mathrm{a} / \widehat{\mathrm{d}=1} .5$

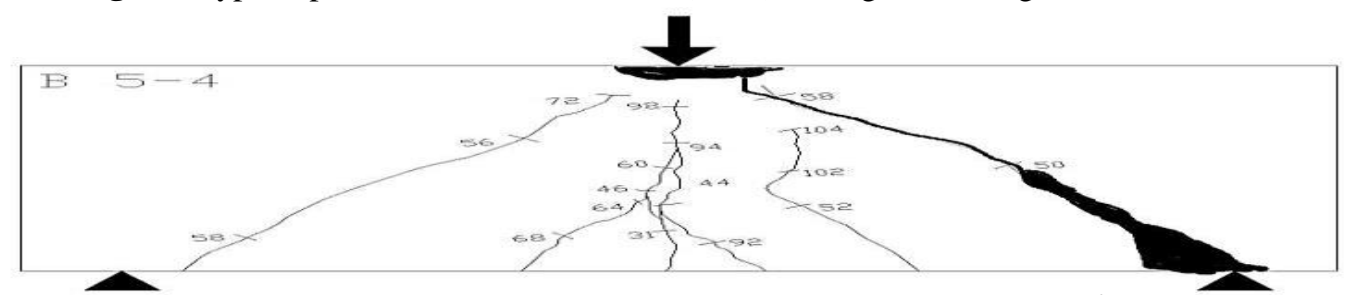

Fig. 21. Typical pattern of cracks for beam (B5-4) having $\mathrm{f}_{\mathrm{cu}}=766 \mathrm{~kg} / \mathrm{cm}^{2}$ and $\mathrm{a} / \mathrm{d}=1$

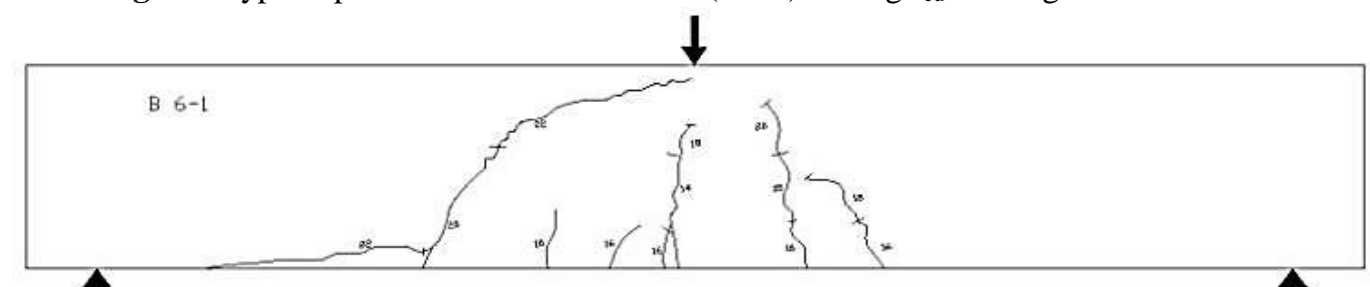

Fig. 22. Typical pattern of cracks for beam (B6-1) having $f_{c u}=766 \mathrm{~kg} / \mathrm{cm}^{2}$ and $\mathrm{a} / \mathrm{d}=3$ 


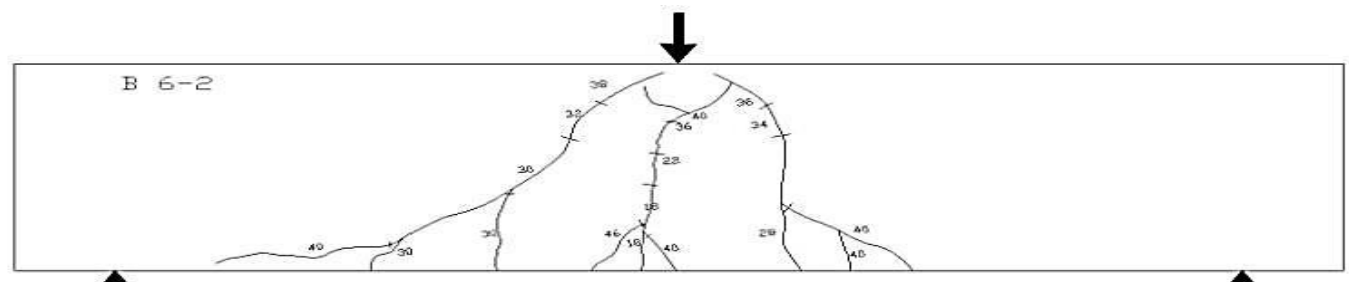

Fig. 23. Typical pattern of cracks for beam (B6-2) having $\mathrm{f}_{\mathrm{cu}}=766 \mathrm{~kg} / \mathrm{cm}^{2}$ and $\mathrm{a} / \mathrm{d}=2$

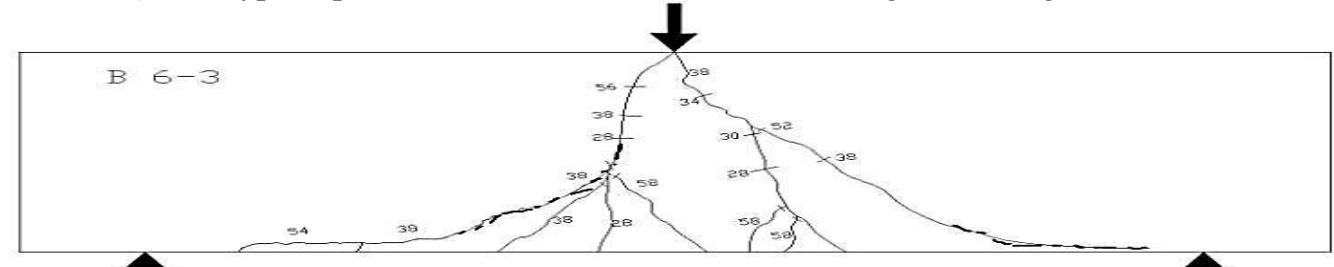

Fig. 24. Typical pattern of cracks for beam (B6-3) having $\mathrm{f}_{\mathrm{cu}}=766 \mathrm{~kg} / \mathrm{cm}^{2}$ and $\mathrm{a} / \mathrm{d}=1.5$

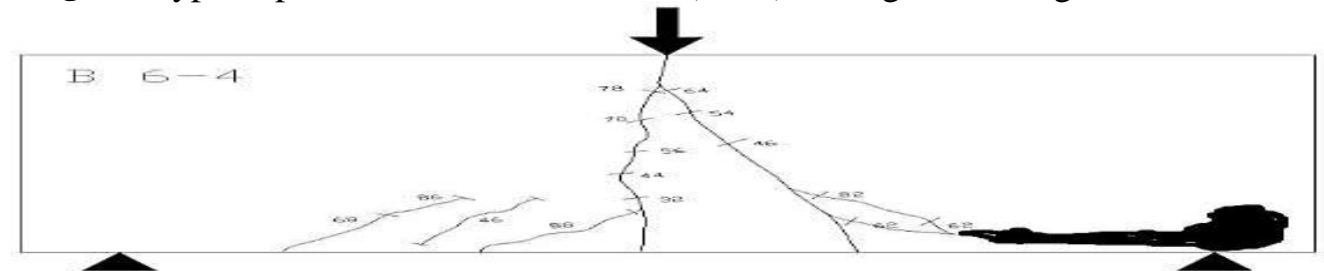

Fig. 25. Typical pattern of cracks for beam (B6-4) having $f_{c u}=766 \mathrm{~kg} / \mathrm{cm}^{2}$ and $\mathrm{a} / \mathrm{d}=1$

Table 3.

Results of the beams tested under transverse static loading

\begin{tabular}{|c|c|c|c|c|c|c|c|c|}
\hline $\begin{array}{l}\text { Group } \\
\text { No. }\end{array}$ & $\begin{array}{c}\text { Beam } \\
\text { No. }\end{array}$ & $\begin{array}{c}\mathrm{f}_{\mathrm{cu}} \\
\mathrm{kg} / \mathrm{c} \\
\mathrm{m}^{2}\end{array}$ & $\begin{array}{c}\text { Stirrups } \\
\text { spacing } \\
(\mathrm{cm})\end{array}$ & $\mathrm{a} / \mathrm{d}$ & $\begin{array}{c}\text { Flexure } \\
\text { cracking } \\
\text { load } \\
\left(\mathrm{P}_{\mathrm{cr}}\right) \\
\text { Ton }\end{array}$ & $\begin{array}{c}\text { Shear } \\
\text { cracking } \\
\text { load } \\
\left(\mathrm{V}_{\mathrm{cr}}\right) \\
\text { Ton }\end{array}$ & $\begin{array}{c}\text { Ultimate } \\
\text { load }\left(\mathrm{P}_{\mathrm{u}}\right) \\
\text { Ton }\end{array}$ & $\begin{array}{c}\text { Failure type } \\
\text { and mode }\end{array}$ \\
\hline \multirow{4}{*}{ G1 } & B1-1 & \multirow{4}{*}{575} & \multirow{4}{*}{20} & 3 & 11 & 11 & 26 & Flexure \\
\hline & B1-2 & & & 2 & 16 & 13 & 42 & Flexure \\
\hline & B1-3 & & & 1.5 & 20 & 16 & 60 & $\begin{array}{l}\text { Shear } \\
\text { tension }\end{array}$ \\
\hline & B1-4 & & & 1 & 28 & 22 & 96 & $\begin{array}{c}\text { Shear } \\
\text { compression }\end{array}$ \\
\hline \multirow{4}{*}{ G2 } & B2-1 & \multirow{4}{*}{766} & \multirow{4}{*}{20} & 3 & 13 & 12 & 28 & Flexural \\
\hline & B2-2 & & & 2 & 17 & 15 & 44 & Flexural \\
\hline & B2-3 & & & 1.5 & 21 & 18 & 62 & Flexural \\
\hline & B2-4 & & & 1 & 31 & 25 & 108 & $\begin{array}{c}\text { Flexural- } \\
\text { shear }\end{array}$ \\
\hline \multirow{4}{*}{ G3 } & B3-1 & \multirow{4}{*}{890} & \multirow{4}{*}{20} & 3 & 15 & 12 & 28 & Flexural \\
\hline & B3-2 & & & 2 & 19 & 17 & 46 & Flexural \\
\hline & B3-3 & & & 1.5 & 23 & 21 & 68 & $\begin{array}{c}\text { Shear } \\
\text { compression }\end{array}$ \\
\hline & B3-4 & & & 1 & 34 & 27 & 112 & $\begin{array}{c}\text { Shear } \\
\text { compression }\end{array}$ \\
\hline
\end{tabular}


JES, Assiut University, Faculty of Engineering, Vol. 44, No. 1, January 2016, pp. 1 - 26

\begin{tabular}{|c|c|c|c|c|c|c|c|c|}
\hline $\begin{array}{c}\text { Group } \\
\text { No. }\end{array}$ & $\begin{array}{l}\text { Beam } \\
\text { No. }\end{array}$ & $\begin{array}{c}\mathrm{f}_{\mathrm{cu}} \\
\mathrm{kg} / \mathrm{c} \\
\mathrm{m}^{2}\end{array}$ & $\begin{array}{c}\text { Stirrups } \\
\text { spacing } \\
(\mathrm{cm})\end{array}$ & $\mathrm{a} / \mathrm{d}$ & $\begin{array}{c}\text { Flexure } \\
\text { cracking } \\
\text { load } \\
\left(\mathrm{P}_{\mathrm{cr}}\right) \\
\text { Ton } \\
\end{array}$ & $\begin{array}{c}\text { Shear } \\
\text { cracking } \\
\text { load } \\
\left(\mathrm{V}_{\mathrm{cr}}\right) \\
\text { Ton } \\
\end{array}$ & $\begin{array}{c}\text { Ultimate } \\
\text { load }\left(\mathrm{P}_{\mathrm{u}}\right) \\
\text { Ton }\end{array}$ & $\begin{array}{l}\text { Failure type } \\
\text { and mode }\end{array}$ \\
\hline \multirow{4}{*}{ G4 } & B4-1 & \multirow{4}{*}{766} & \multirow{4}{*}{14.28} & 3 & 13 & 11 & 28 & Flexural \\
\hline & B4-2 & & & 2 & 18 & 15 & 46 & Flexural \\
\hline & B4-3 & & & 1.5 & 21 & 19 & 66 & Flexural \\
\hline & B4-4 & & & 1 & 32 & 25 & 112 & $\begin{array}{l}\text { Shear } \\
\text { tension }\end{array}$ \\
\hline \multirow{4}{*}{ G5 } & B5-1 & \multirow{4}{*}{766} & \multirow{4}{*}{11.11} & 3 & 12 & 12 & 26 & Flexural \\
\hline & B5-2 & & & 2 & 17 & 16 & 48 & Flexural \\
\hline & B5-3 & & & 1.5 & 21 & 19 & 68 & Flexural \\
\hline & B5-4 & & & 1 & 31 & 26 & 114 & $\begin{array}{c}\text { Shear } \\
\text { compression }\end{array}$ \\
\hline \multirow{4}{*}{ G6 } & B6-1 & \multirow{4}{*}{766} & \multirow{4}{*}{$\begin{array}{l}\text { without } \\
\text { stirrups }\end{array}$} & 3 & 13 & 11 & 22 & $\begin{array}{c}\text { Shear } \\
\text { tension }\end{array}$ \\
\hline & B6-2 & & & 2 & 18 & 14 & 42 & $\begin{array}{l}\text { Shear } \\
\text { tension }\end{array}$ \\
\hline & B6-3 & & & 1.5 & 21 & 18 & 60 & $\begin{array}{l}\text { Shear } \\
\text { tension }\end{array}$ \\
\hline & B6-4 & & & 1 & 32 & 23 & 96 & $\begin{array}{c}\text { Shear \& } \\
\text { anchorage } \\
\text { failure }\end{array}$ \\
\hline
\end{tabular}

\subsection{Load-deflection relations}

The maximum measured deflections of the tested beams at bottom surface of mid span section are plotted versus the applied load from zero loading up to failure in fig. (26) to fig. (31).

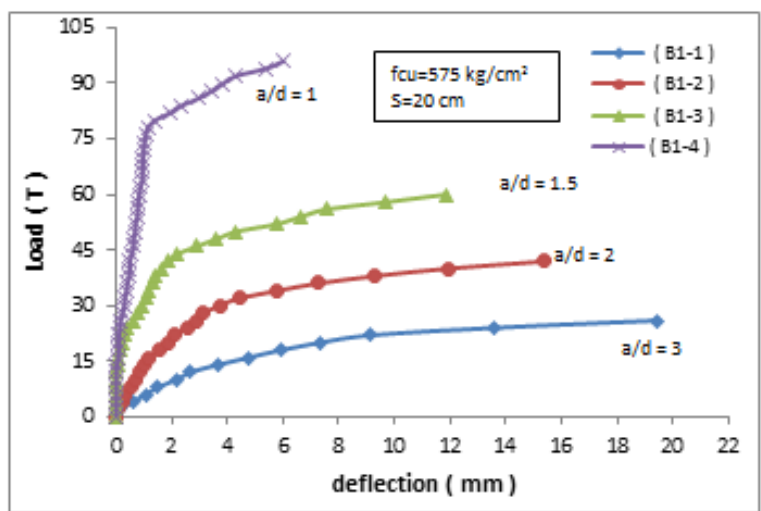

Fig. 26. Load-Deflection relationship for beams of group $(\mathrm{G} 1)$ having $\mathrm{f}_{\mathrm{cu}}=575 \mathrm{~kg} / \mathrm{cm}^{2}$ 


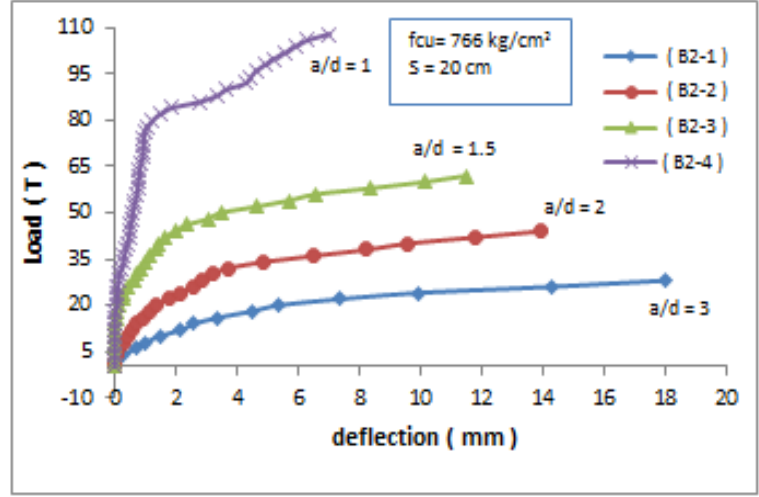

Fig. 27. Load-Deflection relationship for beams of group (G2) having $f_{c u}=766 \mathrm{~kg} / \mathrm{cm}^{2}$

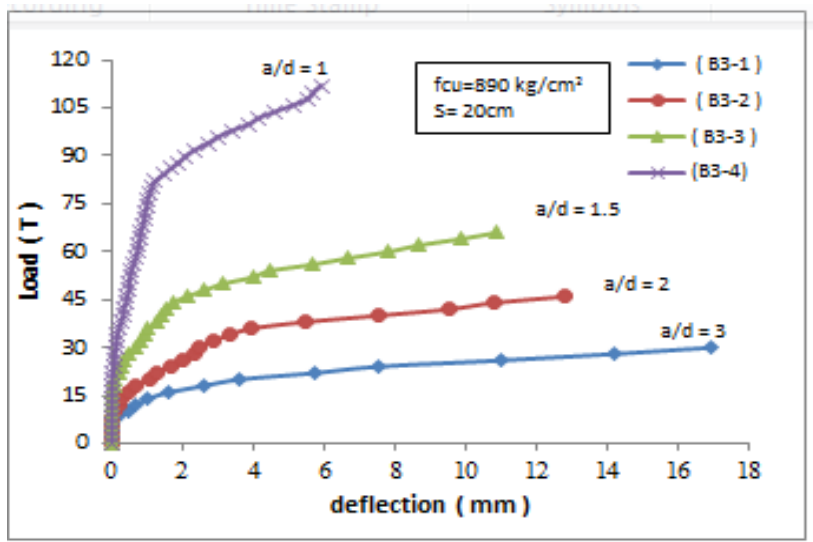

Fig. 28. Load-Deflection relationship for beams of Group (G3) having $f_{c u}=890 \mathrm{~kg} / \mathrm{cm}^{2}$

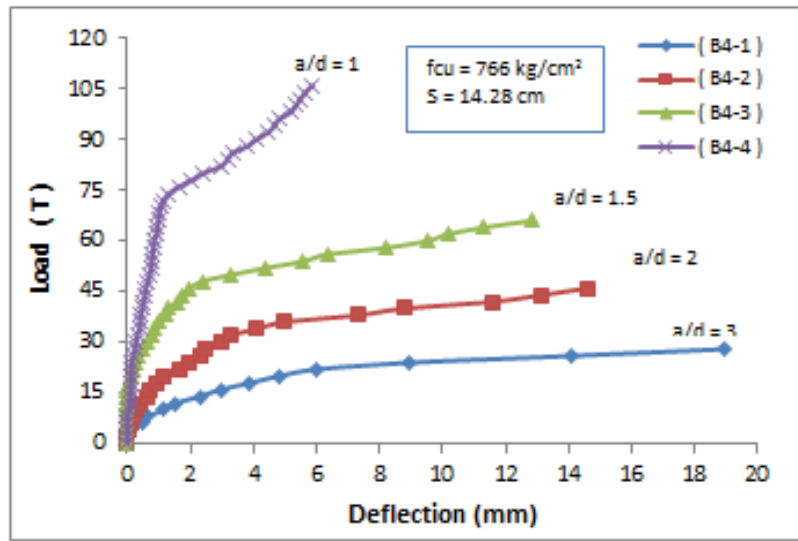

Fig. 29. Load-Deflection relationship for beams of group (G4) having $f_{c u}=766 \mathrm{~kg} / \mathrm{cm}^{2}$ 


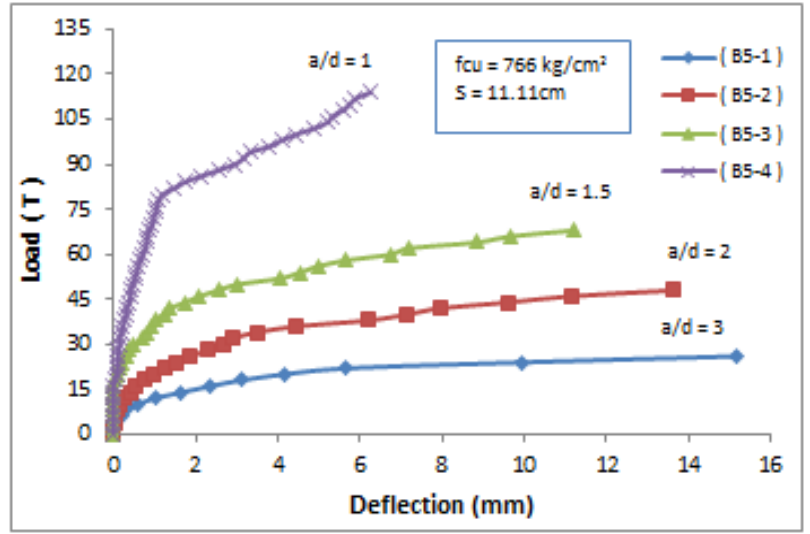

Fig. 30. Load-Deflection relationship for beams of group (G5) having $f_{c u}=766 \mathrm{~kg} / \mathrm{cm}^{2}$

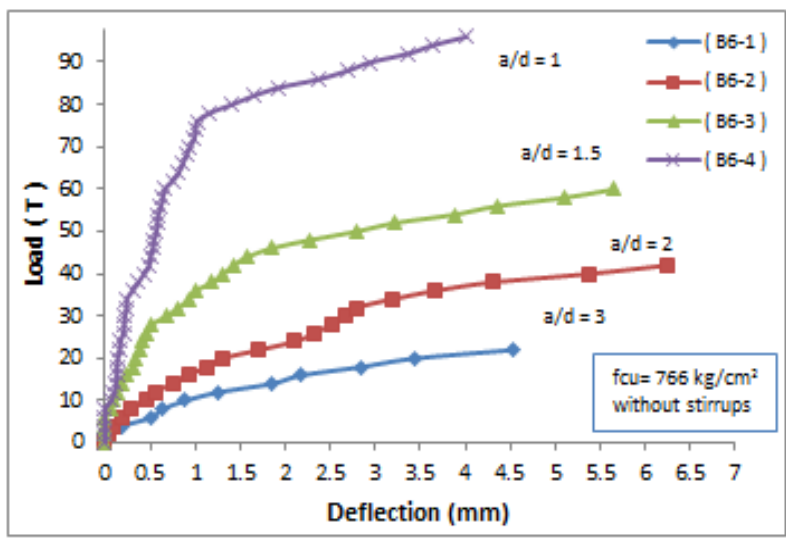

Fig. 31. Load-Deflection relationship for beams of group (G6) having $f_{c u}=766 \mathrm{~kg} / \mathrm{cm}^{2}$

\subsection{Induced strains in the longitudinal tension main steel reinforcement}

Fig.(32) to fig.(37) show the relation between the applied load and induced maximum tensile strain of main steel reinforcement for all tested beams. It was observed that the steel strain increased as the applied load increased up to failure.

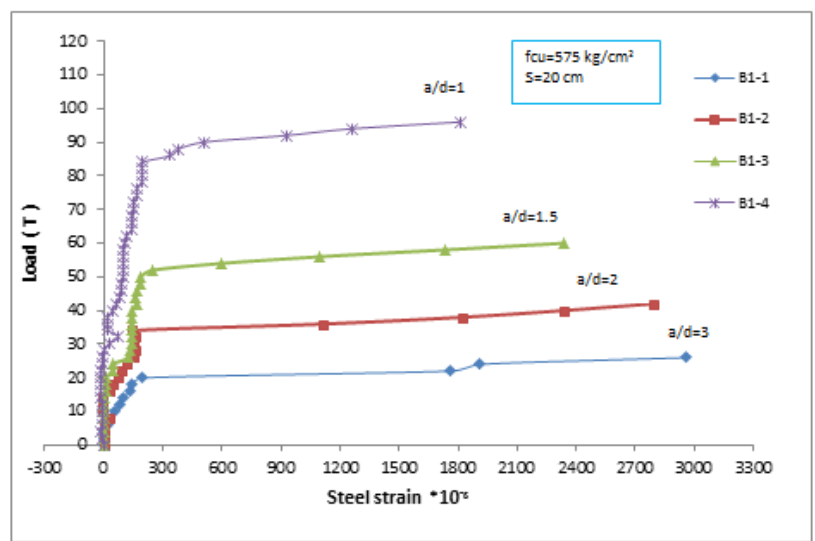

Fig. 32. Load-Steel strain relationship for beams of group (G1) having $f_{c u}=575 \mathrm{~kg} / \mathrm{cm}^{2}$ 


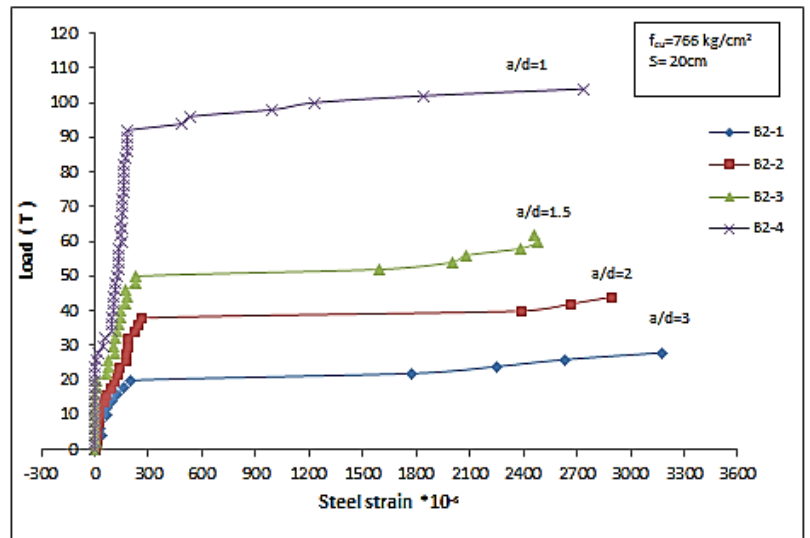

Fig. 33. Load-Steel strain relationship for beams of group (G2) having $f_{c u}=766 \mathrm{~kg} / \mathrm{cm}^{2}$

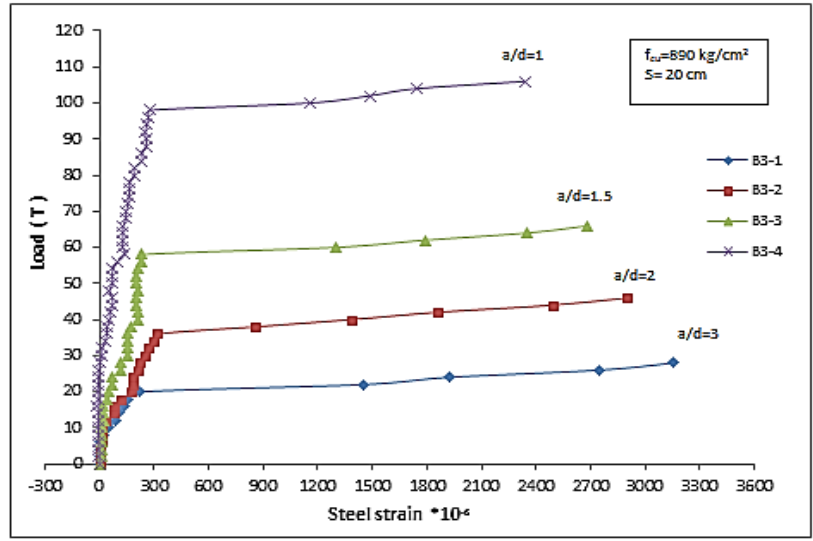

Fig. 34. Load-Steel strain relationship for beams of group (G3) having $\mathrm{f}_{\mathrm{cu}}=890 \mathrm{~kg} / \mathrm{cm}^{2}$

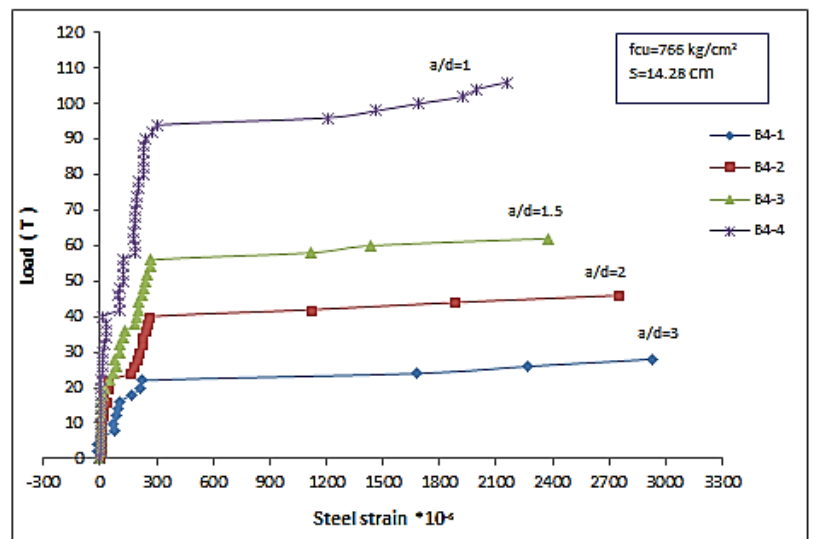

Fig. 35. Load-Steel strain relationship for beams of group (G4) having $f_{c u}=766 \mathrm{~kg} / \mathrm{cm}^{2}$ 


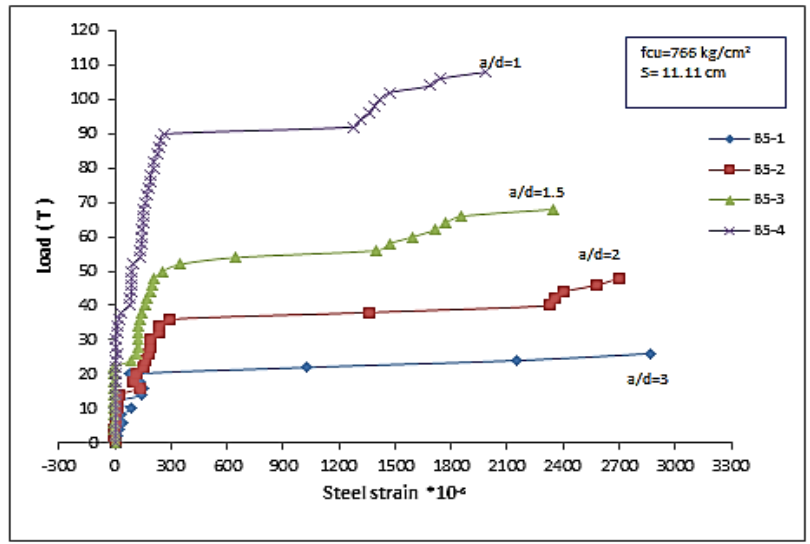

Fig. 36. Load-Steel strain relationship for beams of group (G5) having $f_{c u}=766 \mathrm{~kg} / \mathrm{cm}^{2}$

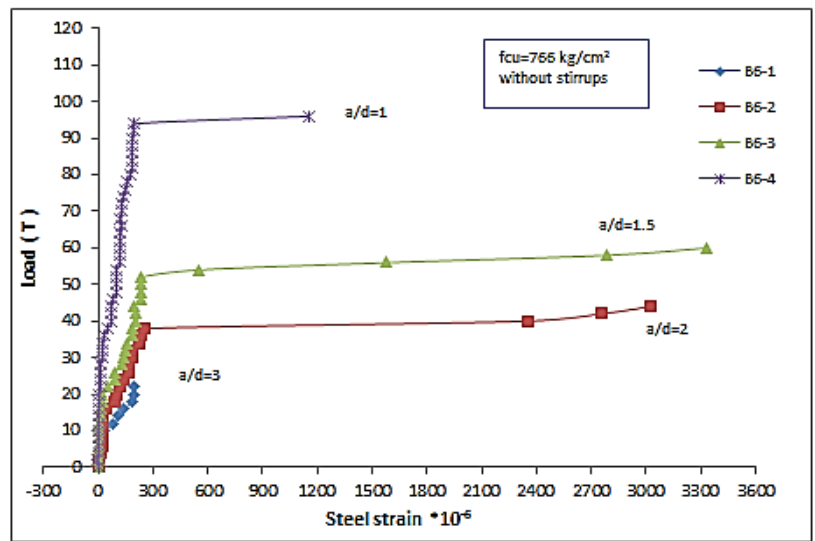

Fig. 37. Load-Steel strain relationship for beams of group (G6) having $\mathrm{f}_{\mathrm{cu}}=766 \mathrm{~kg} / \mathrm{cm}^{2}$

\subsection{Load-concrete strain diagrams}

Fig.(38) to fig.(43) show the relation between the applied load and induced maximum concrete strain for all tested beams, measured at mid span section at the top of the beam. It was observed that the concrete strain increased as the applied load increased up to failure.

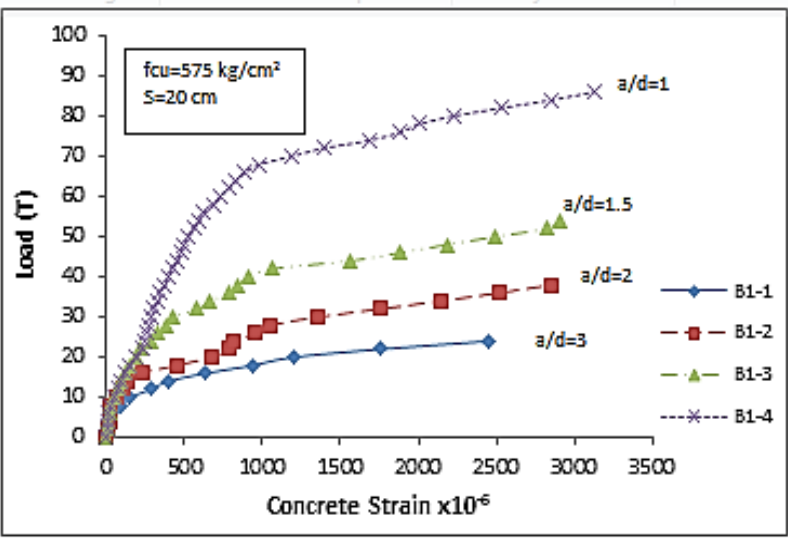

Fig. 38. Load-Concrete strain relationship for beams of group (G1) having $f_{c u}=575 \mathrm{~kg} / \mathrm{cm}^{2}$ 


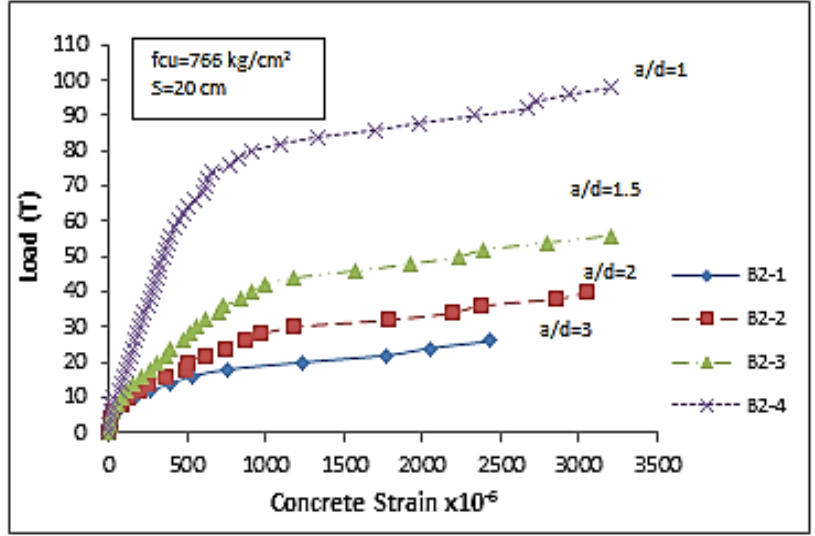

Fig. 39. Load-Concrete strain relationship for beams of group ( $\mathrm{G} 2$ ) having $\mathrm{f}_{\mathrm{cu}}=766 \mathrm{~kg} / \mathrm{cm}^{2}$

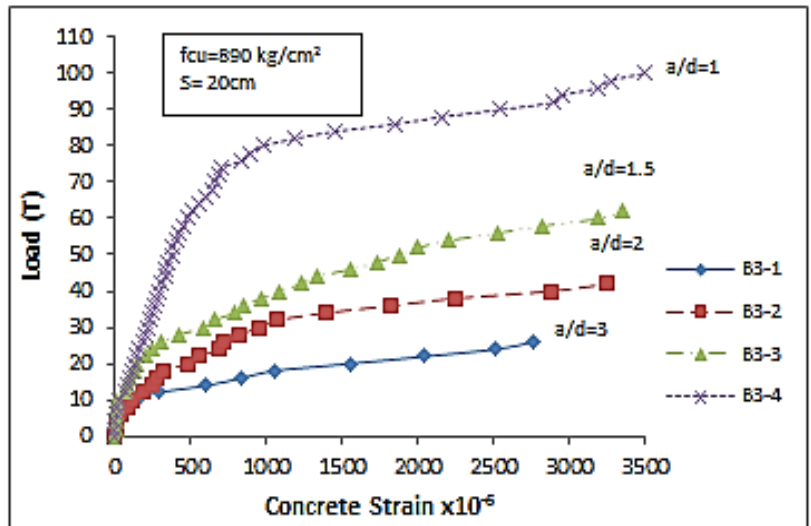

Fig. 40. Load-Concrete strain relationship for beams of group (G3) having $\mathrm{f}_{\mathrm{cu}}=890 \mathrm{~kg} / \mathrm{cm}^{2}$

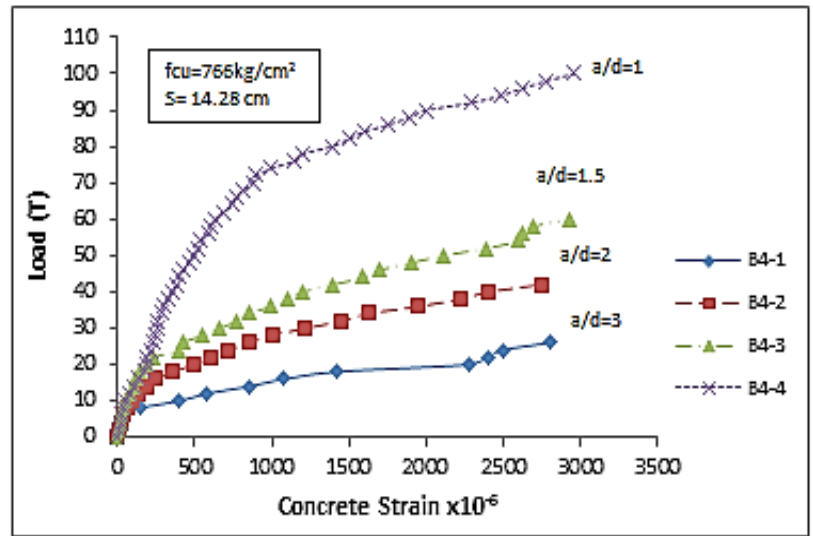

Fig. 41. Load-Concrete strain relationship for beams of group (G4) having $\mathrm{f}_{\mathrm{cu}}=766 \mathrm{~kg} / \mathrm{cm}^{2}$ 


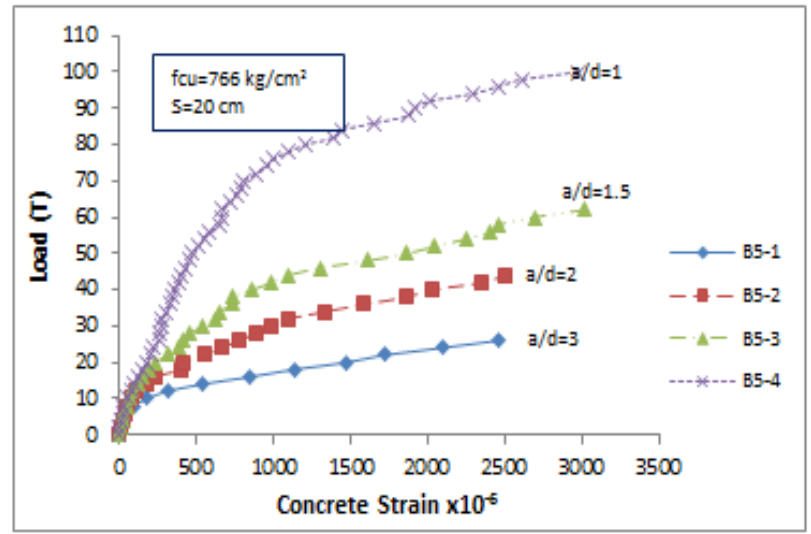

Fig. 42. Load-Concrete strain relationship for beams of group (G5) having $f_{c u}=766 \mathrm{~kg} / \mathrm{cm}^{2}$

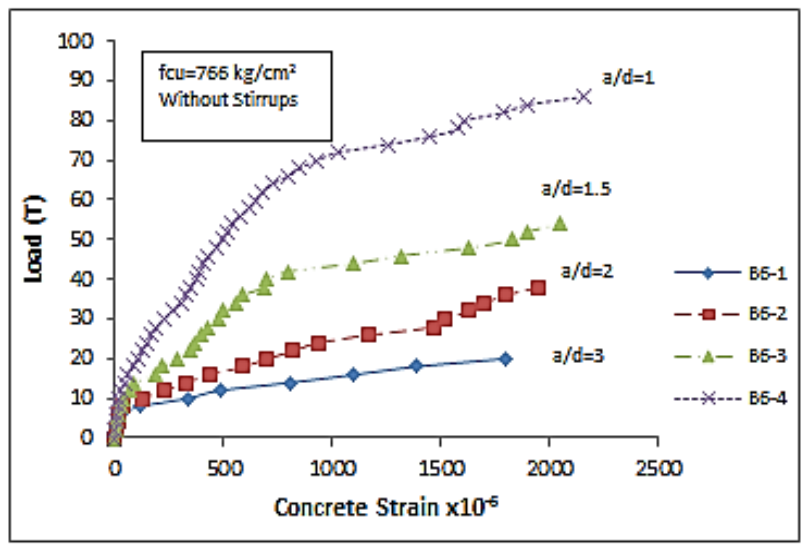

Fig. 43. Load-Concrete strain relationship for beams of group (G6) having $\mathrm{f}_{\mathrm{cu}}=766 \mathrm{~kg} / \mathrm{cm}^{2}$

\section{Discussion of test result}

This item describes and interprets the analysis of the obtained test results of the HSC beams. The analysis includes the relationship between the value of flexural cracking load, shear cracking load and ultimate loads, deflection, concrete strain; and steel strain for tested beams. The values of the experimental measured parameters of tested beams are shown in fig. (2) to fig (43).

\subsection{Effect of shear span to depth ratio}

\subsubsection{With respect to pattern of cracks and modes of failure}

In the early stages of loading, no flexural cracks were observed in the region of bending moment at the mid span of the beam or shear cracks in the shear span as the applied load increased. With further increase of load, flexure cracks formed first at the mid span ,then diagonal cracks formed in the shear span and developed towards the loading point in bending moment area leading to the different modes final failure which is mainly affected by the shear span to depth ratio according to the following cases:-

4.1.1.1 In case of both constant concrete compressive strength and stirrups spacing

From table (3), it is obvious that the failure modes were varied between flexural, shear tension and shear compression. For beams having $\mathrm{a} / \mathrm{d}=3$ and 2 , flexural failure occurred 
except for all beams in group (G6) where in shear failure was noticed, and the most common failure for beams having $\mathrm{a} / \mathrm{d}=1.5$ and 1 was diagonal tension failure accompanied with compression failure. The cracking and the ultimate loads increase as shear span to depth ratio (a/d) decreases from 3 to 1 . This is due to the load transfer mechanism turning from beam action to arch action. As shear span to depth ratio (a/d) decreases, distance from load point to support also decreases and the slope of the cracks become steeper.

\subsubsection{In case of variable concrete compressive strength with constant stirrups spacing}

The higher the compressive strength, the higher is the initial crack load. Also, it is noticed that, the number of cracks and their widths increases in low compressive strength concrete beams. This is due to the increase in tensile strength with the increase of the concrete compressive strength. Decreasing of stirrups spacing has more significant effect on ultimate load, cracks number and width as shear span to depth ratio decreases.

\subsubsection{In case of variable stirrups spacing with constant concrete compressive strength}

For beams in groups (G2, G4, G5 and G6) having the same concrete compressive strength and different stirrups spacing; as stirrups spacing decreases the number of cracks decreases, while beams in (G6)shows fragile and sudden failure.

\subsubsection{With respect to values of flexural cracking load $\left(P_{c r}\right)$ and ultimate load $\left(P_{u}\right)$}

4.1.2.1 In case of both constant concrete compressive strength and stirrups spacing

Flexural cracking load $\left(\mathrm{P}_{\mathrm{cr}}\right)$ increases as shear span to depth ratio decreases. This is related to the load transfer mechanism, as the shear span to depth ratio decreased, a part of the load is transmitted directly to the support by compression strut (arch action), in addition to, the moment decrease which leads to decrease the tension stresses at the extreme bottom fibers . It is clearly shown in fig. (44). Also, it is noticed that, the value of the ultimate load increases as the value of the shear span depth ratio (a/d) decreases, see fig.(45).

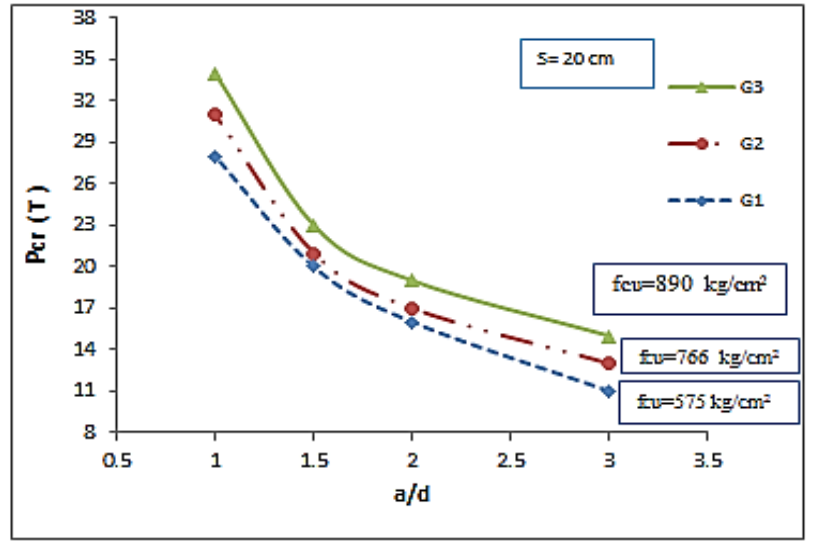

Fig. 44. Effect of the shear span to depth $(\mathrm{a} / \mathrm{d})$ ratio on the cracking load $\left(\mathrm{p}_{\mathrm{cr}}\right)$ 


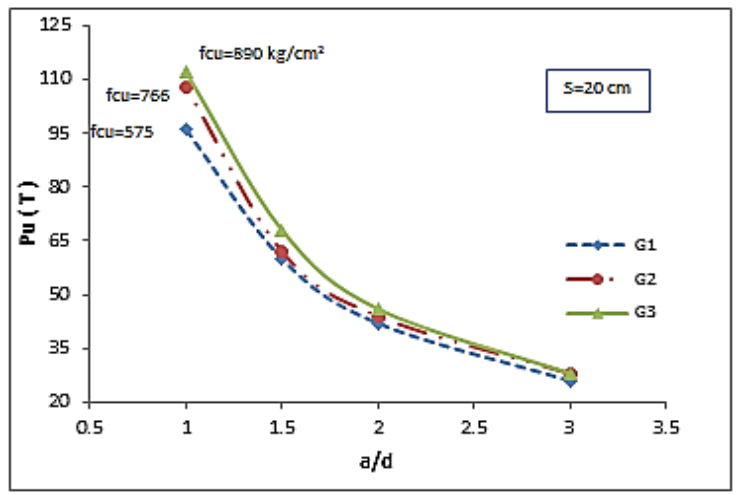

Fig. 45. Effect of the shear span to depth $(\mathrm{a} / \mathrm{d})$ ratio on the Ultimate load $\left(\mathrm{P}_{\mathrm{u}}\right)$

4.1.2.2 In case of variable concrete compressive strength with constant stirrups spacing Concrete compressive strength showed a significant effect in cracking load value. Increasing concrete compressive strength leads to reducing the proportion of voids and permeability between cement granules due to using silica fume, as a result tensile stress is increased, see fig. (46). The value of the ultimate load $\left(\mathrm{P}_{\mathrm{u}}\right)$ slightly increases as concrete compressive strength increases for all tested beams having $(\mathrm{a} / \mathrm{d}=3,2$ and 1.5$)$ except beams having $\mathrm{a} / \mathrm{d}=1$ which failed in shear, it shows significant effect on ultimate load values as concrete compressive strength increases, see fig.(47) .

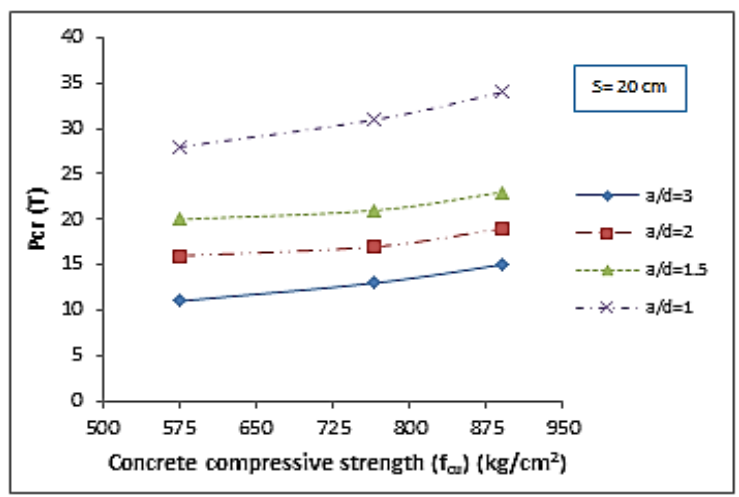

Fig. 46. Effect of the concrete compressive strength on the cracking load

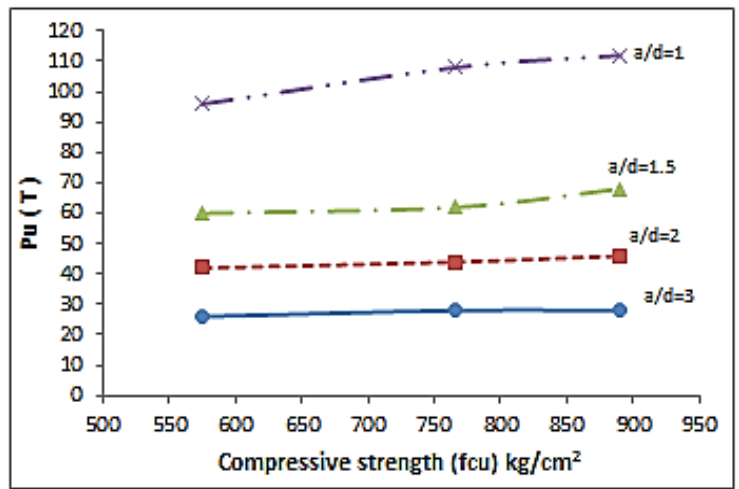

Fig. 47. Effect of concrete compressive strength on $\left(\mathrm{P}_{\mathrm{u}}\right)$ value for groups $(\mathrm{G} 1, \mathrm{G} 2$, and $\mathrm{G} 3$ ) 
Amr Abd El Aal et al., effect of shear span to depth ratio on the statical behavior of HSCB......

4.1.2.3 In case of variable stirrups spacing with constant concrete compressive strength

From table (3), it is noticed that for beams having web reinforcement ,decreasing in stirrups spacing in the specimens beam of Groups ( G2, G4, andG5)didn't show improving in the tensile strength of the concrete. Also, beams without web reinforcement in group (G6) have no distinct clear effect on the results. It was clearly shown in fig. (48).

From table (3), it is also obvious that ultimate load values decreases with the increase of spacing of stirrups. The effect of stirrups spacing on ultimate load becomes more significant as the beams become shorter. Significant increasing of ultimate load for beams having $(\mathrm{a} / \mathrm{d}=1)$ and failed in shear. High strength concrete with stirrups showed less fragile response than similar beams without reinforcement. For beams with the same geometric amount of stirrups, the higher their compressive strength, the more effective stirrups are. The effect of stirrups amount on the ultimate load were plotted in fig. (49).

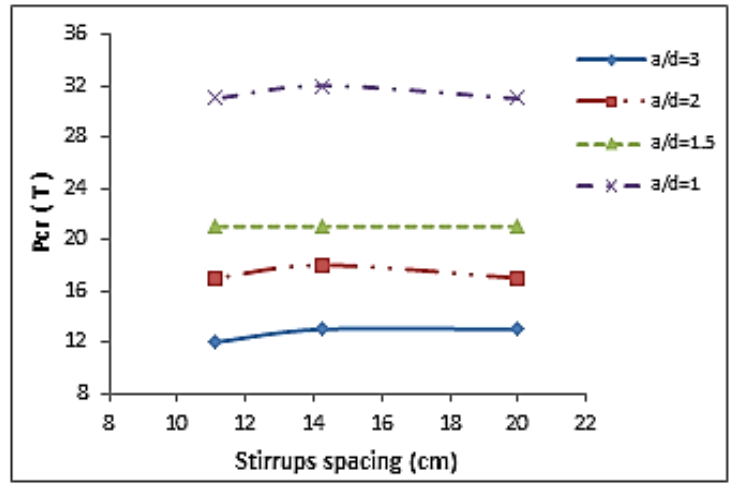

Fig. 48. Effect of stirrups Spacing on the flexural cracking load for beams having $f_{c u}=766 \mathrm{~kg} / \mathrm{cm}^{2}$

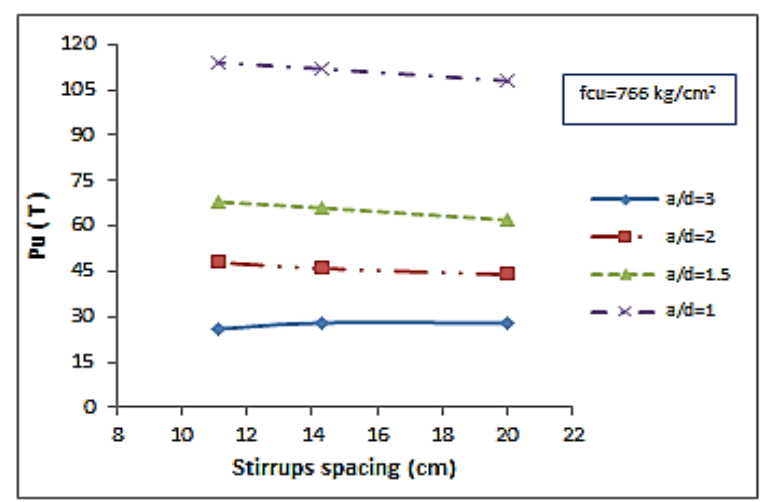

Fig. 49. Effect of stirrups spacing on $\left(\mathrm{P}_{\mathrm{u}}\right)$ value for beams of groups $(\mathrm{G} 2, \mathrm{G} 4, \mathrm{G} 5$, and $\mathrm{G6})$

\subsubsection{With respect to values of shear cracking load $\left(V_{c r}\right)$}

4.1.3.1 In case of both constant concrete compressive strength and stirrups spacing

The value of $\left(\mathrm{V}_{\mathrm{cr}}\right)$ decreases with the increase in $(\mathrm{a} / \mathrm{d})$. As $(\mathrm{a} / \mathrm{d})$ decreases, the slop of the crack becomes steeper. At the same loading level greater crack widths were observed in beams having higher $(\mathrm{a} / \mathrm{d})$, this is because cracks form in the shear span regions at places of high moments which are towards the applied concentrated loads. The relation between experimental shear cracking load $\left(\mathrm{V}_{\mathrm{cr}}\right)$ and $(\mathrm{a} / \mathrm{d})$ ratio was plotted in the fig. (50). 
4.1.3.2 In case of variable concrete compressive strength with constant stirrups spacing

From table (3), it is obvious that for a given shear span to depth ratio (a/d), the value of the cracking shear load $\left(\mathrm{V}_{\mathrm{cr}}\right)$ increases as the value of the concrete compressive strength increases. This due to the increment in tension properties of the concrete, this notice is plotted in fig. (51).

4.1.3.3 In case of variable stirrups spacing with constant concrete compressive strength

The value of the cracking shear load $\left(\mathrm{V}_{\mathrm{cr}}\right)$ for beams with and without stirrups did not greatly affected by the spacing of stirrups. See fig.(52).

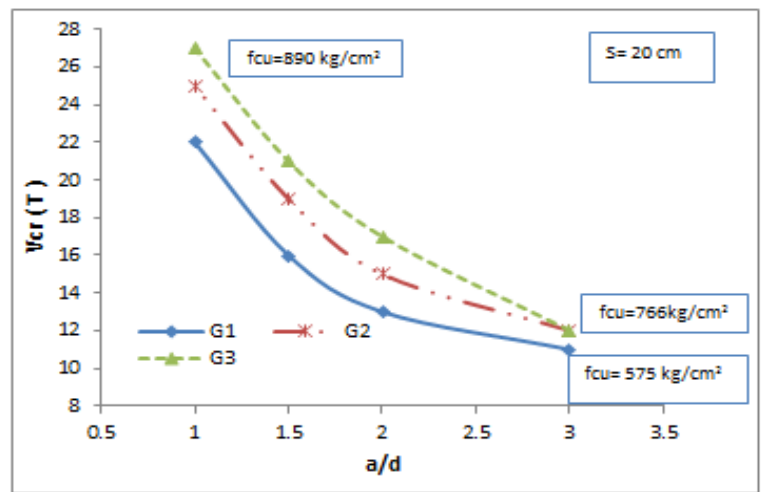

Fig. 50. Effect of (a/d) ratio on the shear cracking load for beams of groups (G1, G2 and G3)

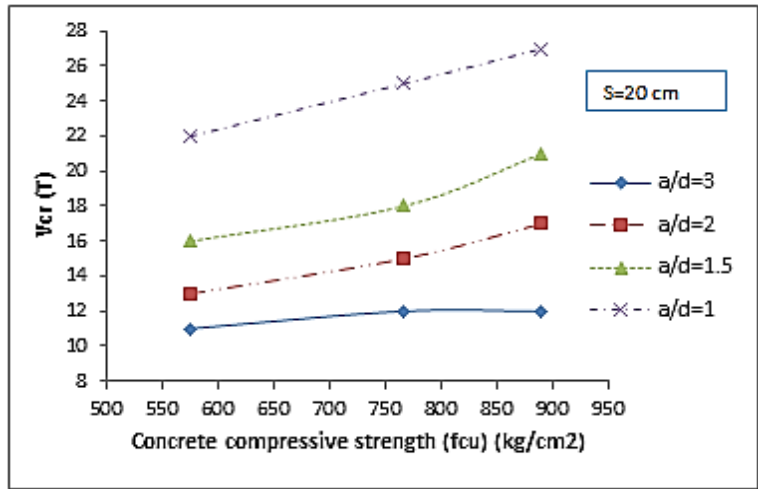

Fig. 51. Effect of concrete compressive strength on the shear cracking load for groups (G1, G2 and G3)

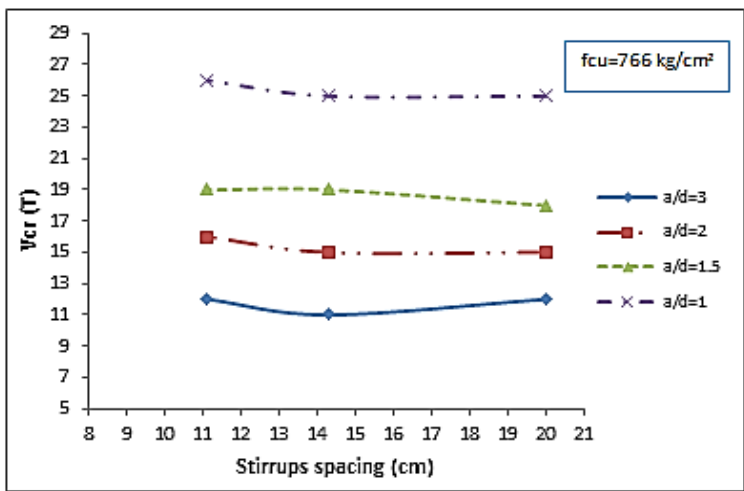

Fig. 52. Effect of stirrups spacing on $\left(\mathrm{V}_{\mathrm{cr}}\right)$ value for beams of groups (G2, G4and G5) 
4.2 Comparison between the experimental results of shear cracking load $\left(V_{c r}\right)$ with that given by different available equations

The aim of this part is to make a comparison between the obtained results and those proposed in ACI 318-code and available equations proposed by researchers such as Zsutty, Rebeiz, Shin et al. and Ahmed Samir equations.

\section{ACI 318 code equation [1]}

$V_{c r}=\left[.156 \sqrt{f_{c}{ }^{\prime}}+17.2 \rho \frac{V u d}{M u}\right] * b_{w} d(\mathrm{~N}, \mathrm{~mm})$

\section{Zsutty's equation [4]}

$V_{c r}=2.1\left(f_{c}^{\prime} \rho \frac{d}{a}\right)^{\frac{1}{3}} * b_{w} d(\mathrm{~N}, \mathrm{~mm})$

Rabeiz's equation [2]

$V_{c r}=\left[.4+\sqrt{f_{c}^{\prime} \rho \frac{d}{a}} *\left(2.7-.4 A_{d}\right)\right] * b_{w} d \quad(\mathrm{~N}, \mathrm{~mm})$

\section{Shin's et al. equation [3]}

$$
V_{c r}=2.6\left(f_{c}^{\prime} \rho\right)^{\frac{1}{3}}\left(\frac{d}{a}\right)^{0.5} * b_{w} d(\mathrm{~N}, \mathrm{~mm})
$$

\section{Ahmed Samir equation [5]}

$$
V_{c r}=2.88\left(f_{c}^{\prime} \rho\right)^{.3}\left(\frac{d}{a}\right)^{0.6} * b_{w} d(\mathrm{~N}, \mathrm{~mm})
$$

The comparison of the experimental results with ACI [1] Eq. (1), Zsutty [4] Eq.(2), Rebeiz [2] Eq. (3), Shin et al. [3] Eq. (4)and Ahmed S. [5] Eq. (5) reveals that (a/d) ratio significantly affects the shear cracking load of high strength concrete beams . For $(\mathrm{a} / \mathrm{d}=2)$ all the aforementioned equations showed good value of shearing cracking load. ACI Eq. showed the best prediction values of shear cracking load for all groups of beams, but for $(\mathrm{a} / \mathrm{d}=1.5) \quad$ a lower values of shear cracking load were observed using ACI and Zsutty equation. On the other hand, Rebeiz, Shin et al. and Ahmed S. equations still show conservative values of shear cracking load. Most of the equations underestimated the shear cracking load at lower a/d ratio $(\mathrm{a} / \mathrm{d}=1)$ except Ahmed $\mathrm{S}$. equation, it was closer and was fair to experimental values for all (a/d) ratios. These results were clearly plotted in curves from fig. (53) to fig. (58). 


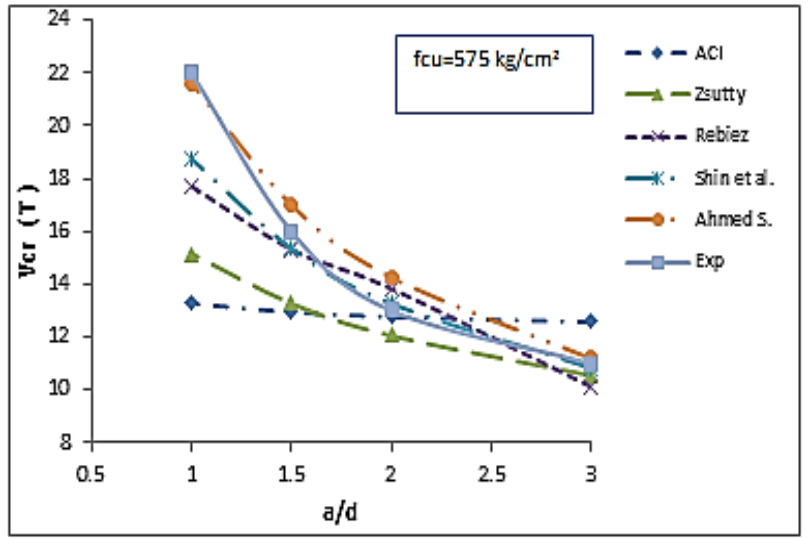

Fig. 53. Comparison between $\mathrm{V}_{\mathrm{cr}(\exp )}$ and $\mathrm{V}_{\mathrm{cr}(\mathrm{cal})}$ for beams of group (G1)

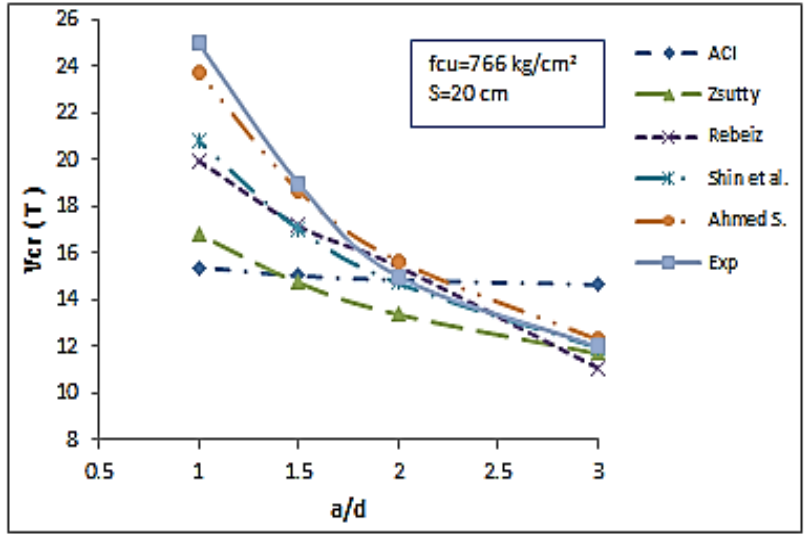

Fig. 54. Comparison between $\mathrm{V}_{\mathrm{cr}(\exp )}$ and $\mathrm{V}_{\mathrm{cr}(\mathrm{cal})}$ for beams of group $(\mathrm{G} 2)$

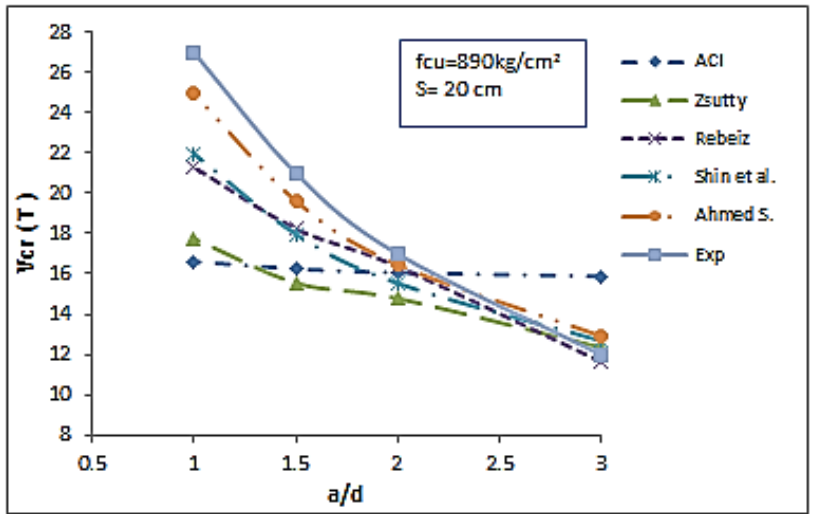

Fig. 55. Comparison between $\mathrm{V}_{\mathrm{cr}(\exp )}$ and $\mathrm{V}_{\mathrm{cr}(\mathrm{cal})}$ for beams of group (G3) 


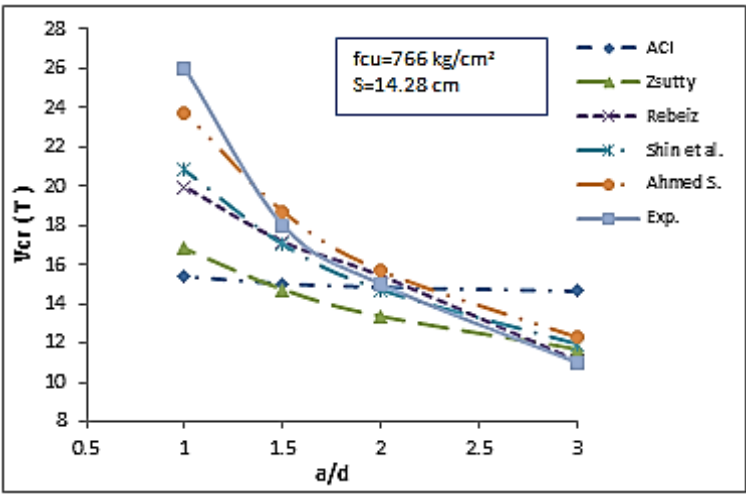

Fig. 56. Comparison between $V_{\text {cr(exp) }}$ and $V_{\text {cr(cal) }}$ for beams of group $(G 4)$

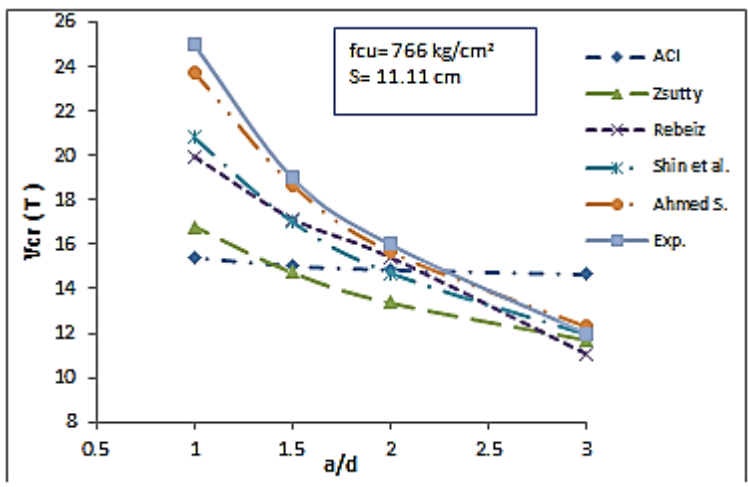

Fig. 57. Comparison between $\mathrm{V}_{\mathrm{cr}(\exp )}$ and $\mathrm{V}_{\mathrm{cr}(\mathrm{cal})}$ for beams of group(G5)

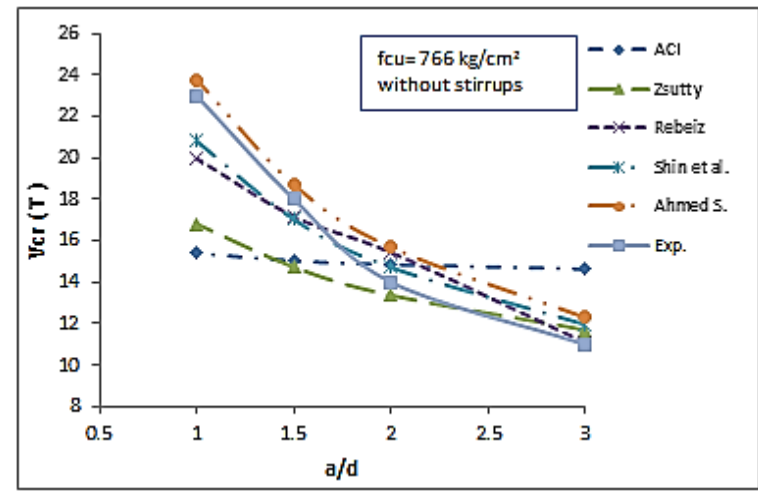

Fig. 58. Comparison between $\mathrm{V}_{\mathrm{cr}(\mathrm{exp})}$ and $\mathrm{V}_{\mathrm{cr}(\mathrm{cal} .)}$ for beams of group (G6)

\section{Conclusions}

Based on the obtained test results and their analysis, the following conclusions and recommendations may be drawn out:

1- The maximum measured deflection increases, with the increase of shear span to depth ratio, where the beam becomes flexible and the effect of the arch action of the beam decreases. In addition, the maximum deflection decreases with the increase of 
concrete strength due to the increasing of the flexural stiffness of the beam. The stirrups spacing have a slight significant effect on the load- deflection relationship.

2- The maximum induced main steel strain decreases directly with decreasing the $(a / d)$ ratio while it increases with the increase of concrete strength $\left(f_{c u}\right)$, but, it decreases by decreasing stirrups spacing.

3- The maximum concrete strain decreases with the increase of shear span to depth ratio and increases with the increase of concrete strength $\left(\mathrm{f}_{\mathrm{cu}}\right)$, and slightly increases with the decrease of stirrups spacing.

4- Flexural cracking load $\left(\mathrm{P}_{\mathrm{cr}}\right)$ increases as shear span to depth ratio decreases. This is related to the load transfer mechanism; as the shear span to depth ratio decreased a part of the load is transmitted directly to the support by compression strut (arch action), and increases with increase concrete compressive strength. Meanwhile stirrups spacing have no distinct clear effect on the cracking load value.

5- The value of shear cracking load $\left(\mathrm{V}_{\mathrm{cr}}\right)$ decreases with the increase in $(\mathrm{a} / \mathrm{d})$ and increases as the value of the concrete compressive strength increases. On the other hand, shear cracking load value didn't greatly affected by the spacing of stirrups, it just shown a slight increment for beams having small a/d ratios.

6- Ahmed S. [5] eq.(5) showed to be the most good prediction for evaluating the value of shear cracking load for all the tested beams with and without stirrups, it was closer and was conforms fairly with experimental values for all (a/d) ratios.

7- The ultimate load value increases as the value of the shear span depth ratio $(\mathrm{a} / \mathrm{d})$ decreases due to the fact that a part of the load is transmitted directly to the support by compression strut (arch action) and the slope of the cracks become more steep.

8- The value of the ultimate load $\left(\mathrm{P}_{\mathrm{u}}\right)$ has a slight increase as concrete compressive strength increases for beams having $\mathrm{a} / \mathrm{d}=3,2$ and 1.5 , but for beams having $\mathrm{a} / \mathrm{d}=1$ which mainly failed in shear, it showed significant effect on ultimate load values as concrete compressive strength increases.

9- The effect of stirrups spacing on the ultimate load value becomes more significant as the beams become shorter. Significant increasing of ultimate load for beams having $\mathrm{a} / \mathrm{d}=1$ and failed in shear was recorded. High strength concrete beams with stirrups showed a less fragile response than similar beams without web reinforcement.

10-It is recommend that further researches are required to illustrate the effect of shape of reinforced concrete beams cross-section, say T-section or L-section as affected by shear span to depth ratio having different grades specially for HSC.

\section{Notations}

$\mathrm{a}=$ Shear span $(\mathrm{mm})$

$\mathrm{b}=$ Beam width (mm)

$f_{c u}=$ Cube compressive strength $\left(\mathrm{kg} / \mathrm{cm}^{2}\right)$

$\mathrm{V}_{\mathrm{u}}=$ Ultimate shear load ( $\left.\mathrm{T}\right)$

$\rho=$ Longitudinal main steel reinforcement ratio, (As / b d)

$f_{c}{ }^{\prime}=$ Concrete cylinder compressive strength $\left(\mathrm{N} / \mathrm{mm}^{2}\right)$

$\mathrm{V}_{\text {cr(exp) }}=$ Load at which first shear cracking occurs (at shear span) (T)

$\mathrm{P}_{\mathrm{u}}=$ The experimental ultimate load $(\mathrm{T})$

$\mathrm{P}_{\mathrm{cr}}=$ Load at which first flexural cracking occurs (bottom of mid span) (T)

$\mathrm{M}_{\mathrm{u}}, \mathrm{V}_{\mathrm{u}}=$ Factored moment and shear 


\section{REFERENCES}

[1] ACI Committee 318, Building Code Requirements for Structural Concrete (ACI 318-08) and Commentary (318R-02), American Concrete Institute, 2008.

[2] Rebeiz, K. S., "Shear Strength Prediction for Concrete Members," ACI Structural Journal, Vol. 125, No. 3, pp. 301-308, March 1999.

[3] Shin, S., Lee, K., Moon, J., and Ghosh, S. K., "Shear Strength of Reinforced High-Strength Concrete Beams with Shear Span-to-Depth Ratios between 1.5 and 2.5," ACI Structural Journal, Title no. 96-S61, pp. 549-556, July-August 1999.

[4] Zsutty, T. C., "Beam Shear Strength Prediction by Analysis of Existing Data," ACI Structural Journal, Proceedings V. 65, No. 11, pp. 943-951, Nov. 1968.

[5] Ahmed Samir Abdalla "Shear Strength of High Strength Concrete Beams" M.Sc. thesis, Faculty of Engineering, Zagazig University, 2005. 


\section{تأثير نسبة بحر الثص الى العمق على السلوك الاستاتيكي للكمرات

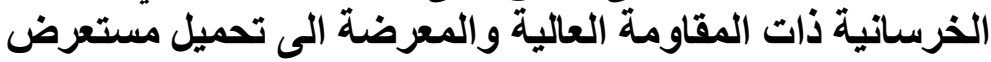

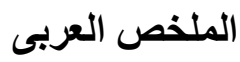

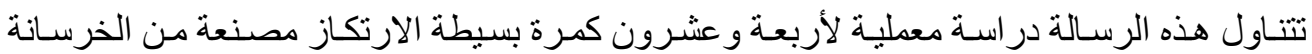

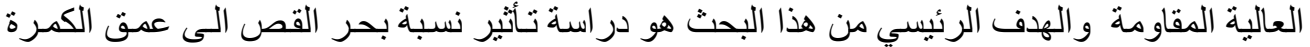

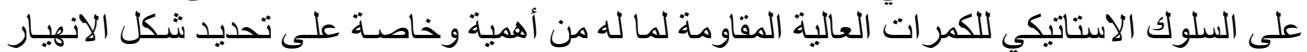

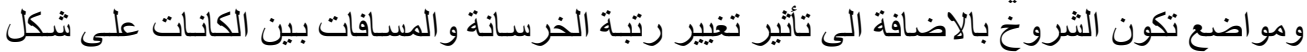

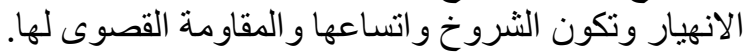

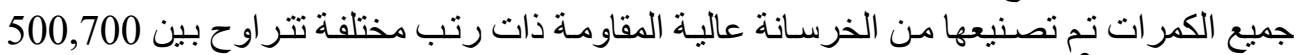

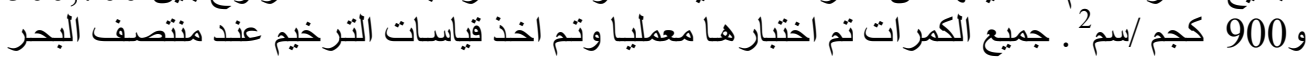

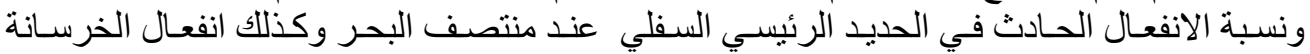

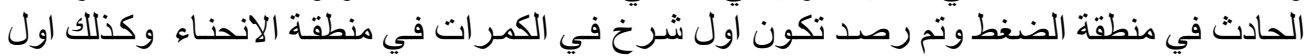

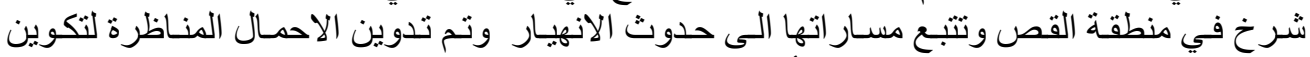

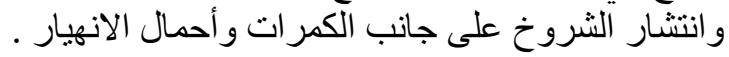

\section{أهم النتائج المستخلصة من هذا البحث وهي}

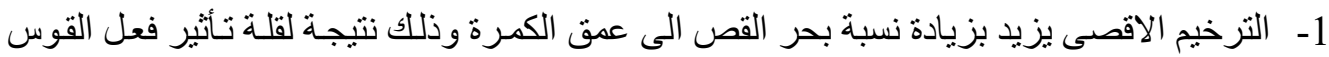

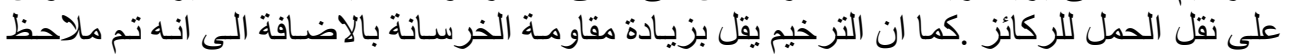

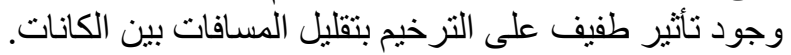

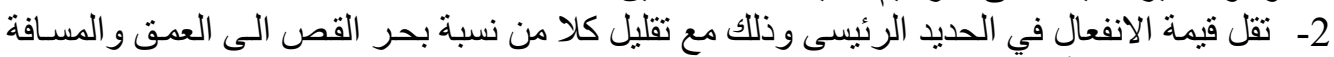

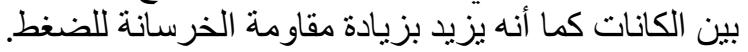

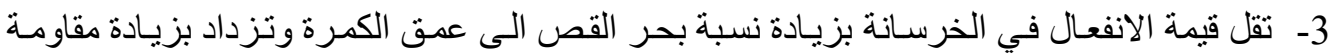
الخرسانة للضغط. 4- تزيد قيمة حمل ظهور اول شرخ (حمل التشريخ) في منطقة الانحناء كلما قلت نسبة بحر القص الى الى

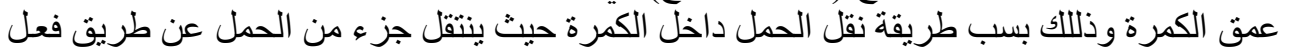

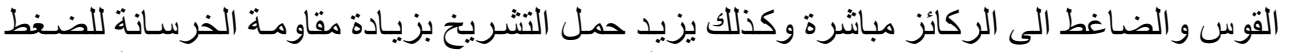

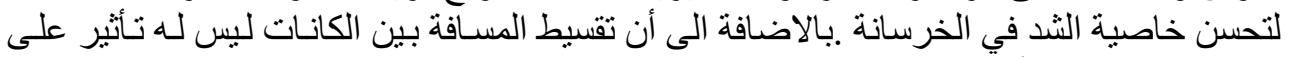

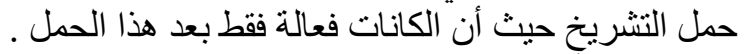

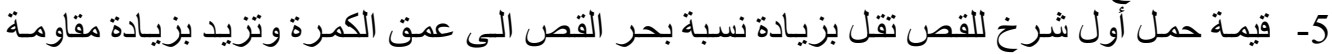
الخرسانة و لا تتأثر بتقليل المسافات بين لفئ الكانات.

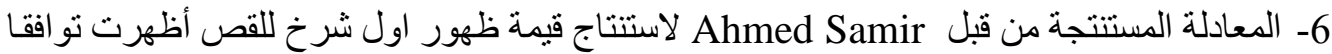

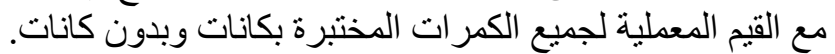

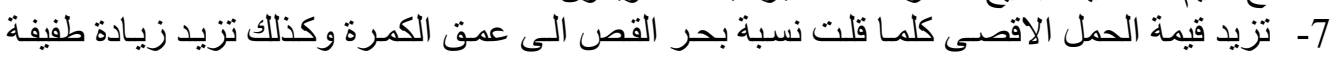

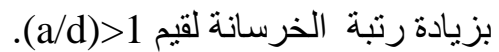

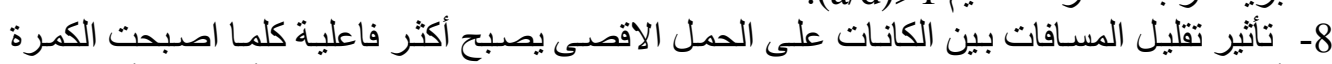

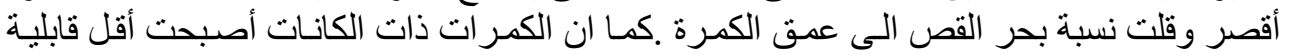

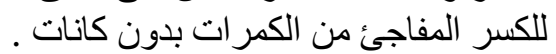

